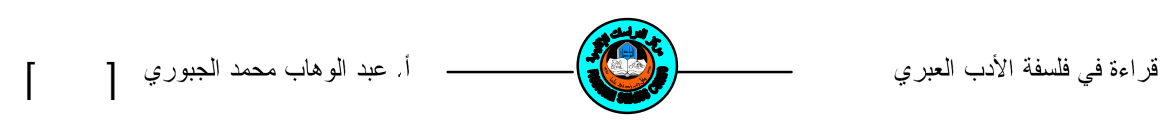

$$
\begin{aligned}
& \text { اتجاهات الادب الإسر ائيلي وهلسفته } \\
& \text { عبد الوهاب محمد الجبوري* }
\end{aligned}
$$

$$
\text { مستخلص بحت }
$$

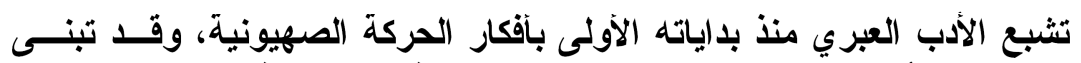

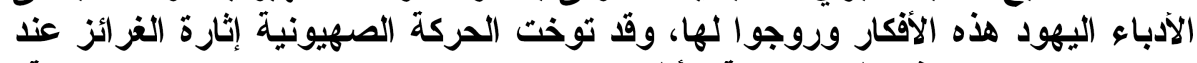

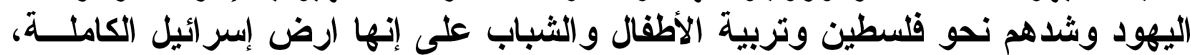

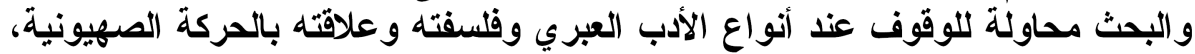

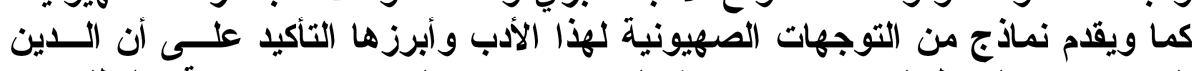

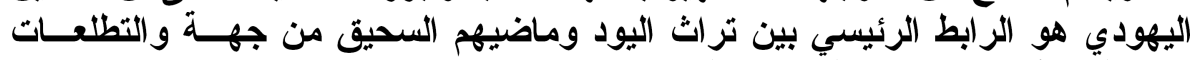

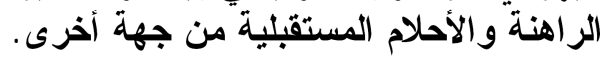

المقدمه

تشبع الادب العبري مند بداياته الاولى باقكار الحركه الصهيونيه وان الادباء

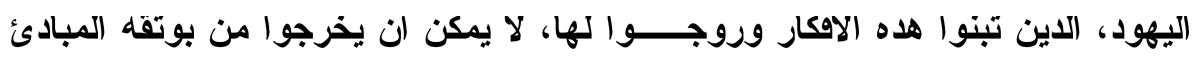

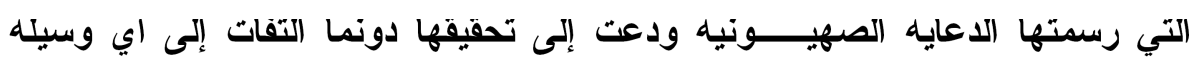

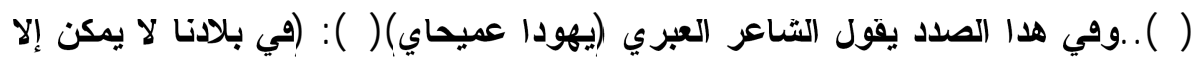

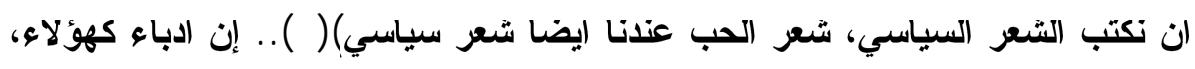
لا يمكن ان يترجموا احاسيسهم إلا بما زج في نفوسهم صغارا وشبوا عليه تيانا ومارسوه كبارا ل...

* مدرس مساعد/ كلية الآداب/ جامعة الموصل * م 
قالغايه التي توختها الحركه الصهـيونيه مند البلايات الاولى لتاسيسها، والتي انعكست بلورها على الادب العبري، هي إتارة الفرائز العلوانيه لاى اليهود من جهه

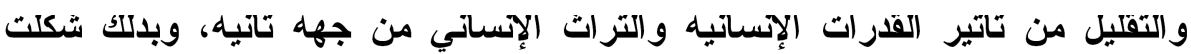
العدواتيه والعنصريه والحقد والاتاتيه سمات خطيرة في الشخصيه اليهوديه بوجهيها الإسر ائيلي والإسر ائيلي، حتى اصبحت لا تحفظ عها ولا تراعي حق جوار ولا تكترث

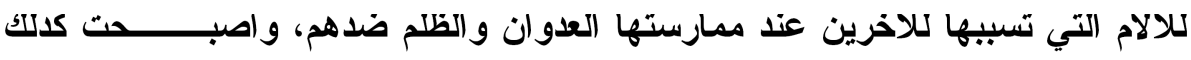
فلفدة الإحساس، ليس بمظهر اللامبالاة وحسب، وإنما (يضا بمعنى الشخصيه المجردة

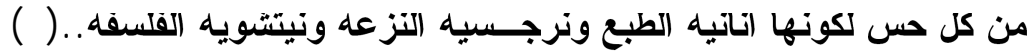
و استمرت هله الاتجاهات الصهيونيه غالبه على الادب العبري حتى بعد تاسيس

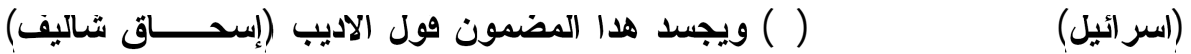
(7)الدي فال: (علينا ان نعلم الشباب على اساس ارض إسرائيل الكامله، وهلا الامر لانيل با ان يتم بواسطه الادباء، وي رياض الاطفال والمدارس وحركه الشباب والجندي و القائد في الجيش، وبالقعل وقد استطاع الادب العبري ان يقوم بهدا الدور على احسن ما يكون) (V)... كما اضيقت إلى هله الاتجاهات (يضا موضوعات جليدة سواء كاتت مستمدة من المجتمع اليهودي الإستيطاني الإحتلالمي او ورضتها الاحداث التاريخيه التي مرت بها المنطقه وعبر ويها الادب العبري عن وجها نظر الحركه الصهيونيه واهداوها.. ولاهميه موضوع البحث من الناحيتين الفكريه والعلميه تم تناوله على الثكل

$$
\text { I. أتواع الادب العبري... }
$$$$
\text { r. الحركه الصهيونيه والادب العبري.. }
$$$$
\text { r. علسفه الادب العبري.. }
$$

ع. نمادج من الاتجاهات الصهيونيه للادب العبري...

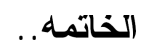




$$
\text { انواع الادب العبري }
$$

وبل التطرق إلى مفهوم مصطلح الادب العبري وافسامه نشير إلى ان هناك مصطلحات اساسيه وي هلا الادب، وهي مصطلحات تشتمل على خمسه إنواع هي: الادب اليهودي، الادب الصهيوني، الادب الإسرائيلي، الادب الياليشي وفي والادب العبري، ولكل من هده المصطلحات فترته الزمنيه ودلالاته ولغته ومؤلقوه ايضا.. هالادب اليهودي عبارة تستخدم لتصنيف بعض الاعمال الادبيه، إما من منظور مضمونها او من منظور الاتتماء الاتتي او الديني لكاتبها، فالاعمال الادبيه التي تتناول

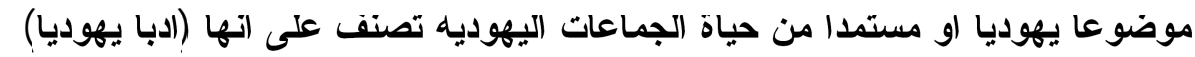

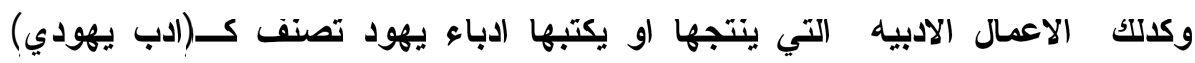

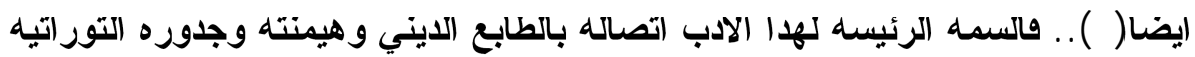
وعدم وجود حدود جغراويه وتقافيه وتاريخيه ناظمه له.. ومرجعيته الاساسيه هي المصادر الدينيه اليهوديه الرئيسه [العهل القديم، باجزائه التلاته التوراة والآنبياء و المكتوبات، والتلمود) وهو ينقسم إلى فسمين، الاول: ادب يهودي وديم وكتابات

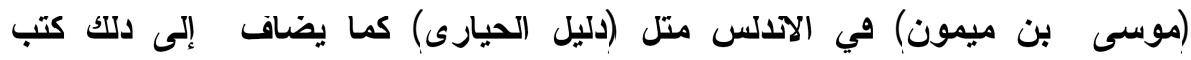
المتصوهين اليهود (الحسيديم).. وهلا المصطلح عام ومجرد، وهو يصف جاتبا واحدا من جواتب الادب ويتجاهل عنصر اللغه الدي يميز ادب ووم عن اهوام اخرين (9)...

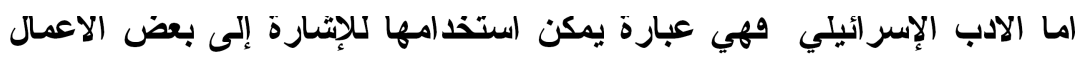
الادبيه دات المضمون الإسرائيلي الواضح، بغض النظر عن الاتتماء القومي او الديني

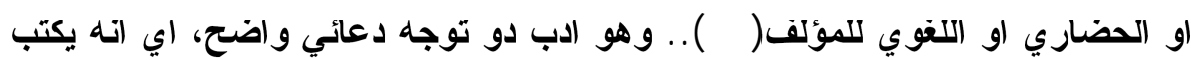
لينشر في الصحاهه ووسائل الإعلام.. ولا يصف ها المصطلح شكل الادب ولا محتواه

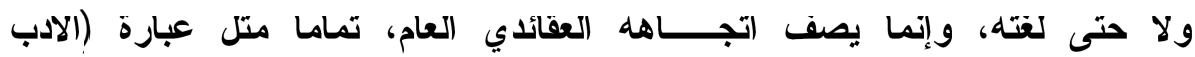

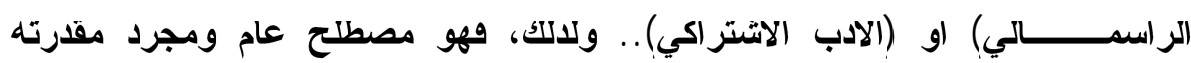

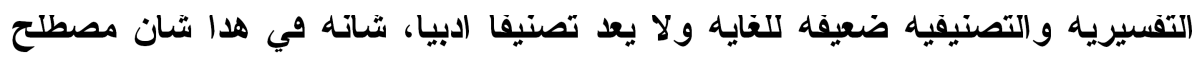
الادب اليهودي او الادب العبري| (1) 1 ).. 
وهدا الادب يغلب عليه الفكر الإيديولوجي الإسرائيلي مند البلايات الاولى

لتشكل الحركه الصهيونيه عقب ظهور البروتستانتيه وي اوربا في القرن السادس عشر، التي سهلت عمليه الافتاح على التراث اليهودي القليم بوصف التوراة الجزء الاول

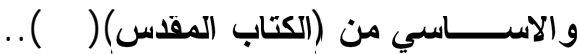

هن هنا لا نستغرب ان اوائل الدين كتبوا ادبا صهيونيا مبشر ا بالفكر الإسرائيلي لم يكونوا يهودا وإنما كانوا من الاوربيين من امتال الروائيه الإنكليزيه (جورج اليوت)

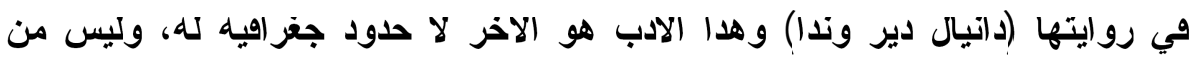
الضروري ان يكتبه يهودي، ويسقط عنه عامل التوحيا اللفوي وقل كتب بلفات عدة حسب الاصل التقافي والقومي لكاتبيه، ومتلا من المكن القول بوجود ادب صهيوني هرنسي واخر إنكليزي وتالث عبري أوهو حليث موضوعنا في هدا (البحث) ما دام هدا الادب مصبوغا بالصبغه الصهيونيه كايديولوجيه (II).. اما الادب الإسرائيلي وهي عبارة تستخلم للإثشارة إلى الادب المكتوب بالعبريه

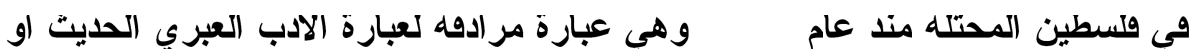
المعاصر.يويمكن اعتبار ها الادب يهوديا لان معظم كتابه من اليهود غالبا، وادبا صهيونيا لاعتماده الايديولوجيه الصهيونيه وي معظم مؤلقاته، وادبا عبريا لان مؤلقاته

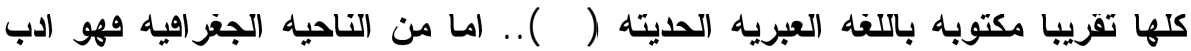
محصور ضمن حدود ولسطين المحتله، ولكن ها ا لم يمنع من وجود ادب إسرائيلي

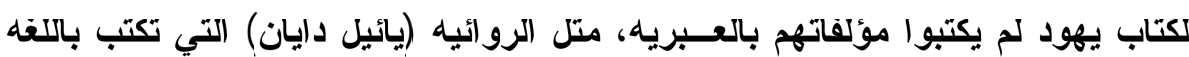

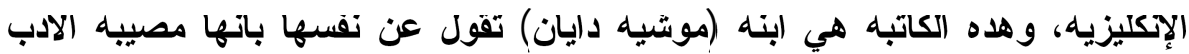
الإسر ائيلي دلك لاتها يهوديه و إسر ائيليه وتؤمن بالصهيونيه، لكنها تكتب بالإنكليزيه عن الإنه

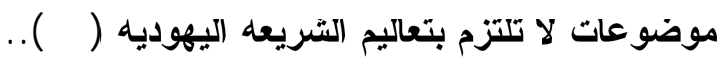

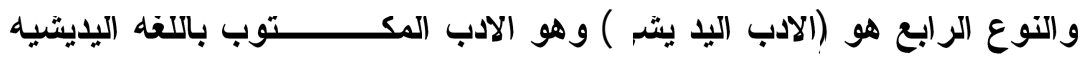

(17)... و ظهرت اول اعمال ادبيه يديشيه وي القرن السادس عشر، وكاتت ترجمات للاداب الغربيه وكتب الصلوات، وصد استخدم بعض دعاة حركه التتوير في شرق اوربا،

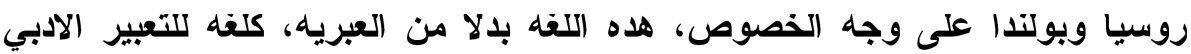
باعتبار اتها لغه حيه وتتحدث بها الجماهير اليهوديه من يهود البليشيه، تم ظهر

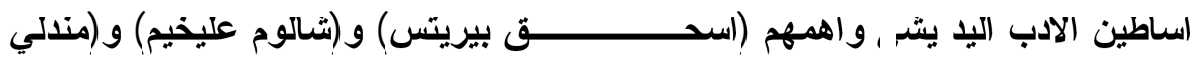

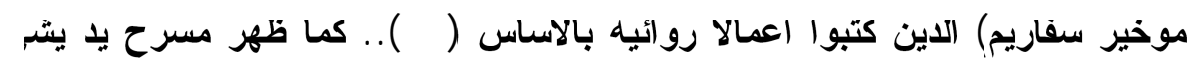




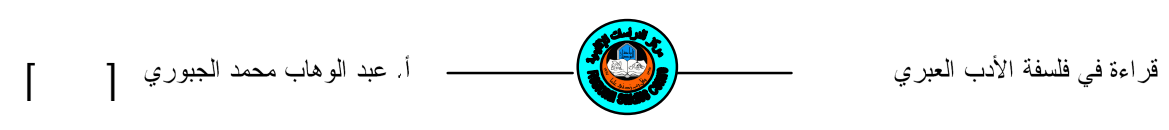

عام • AVV في روسيا تم تطور ونما في الولايات المتحدة والارجنتين حيث حمل اليهود المهاجرون الروس اليهود اللفه اليديشيه او اللهجه اليديشيه معهم والتي اصبحت لفه الثارع في المهجر.يوف تمتع الادب اليديشي بمرحله من من الازدهار

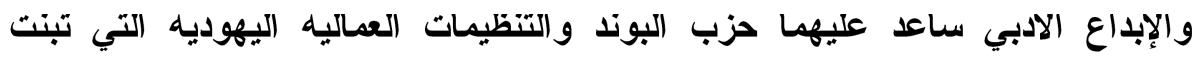

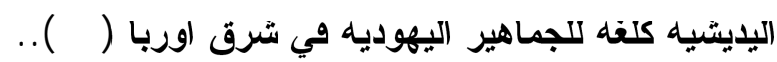
لكن وترة الازدهار هده كاتت وصيرة للغايه، واليديشيه لم تستخدم كلفه للتعبير الادبي إلا نهايه القرن التاسع عشر، اي اته لم يكن هناك ترات يايشي.. بعد نهايه

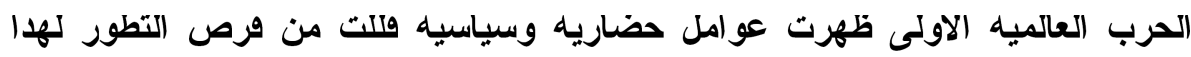
الادب من الهمها ان يهود اليديثيه اتفسهم اتدمجوا في محيطهم الحضاري لإلروسي والامريكي)، وادى هلا إلى تحديد استخدام اليديشيه بشكل عام(19)..

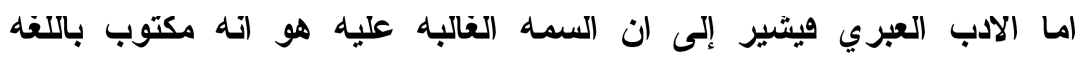
العبريه، وهو اصطلاح عام يشير إلى الاتتماء اللفوي للعمل الادبي ولا يغطي الاتتماء

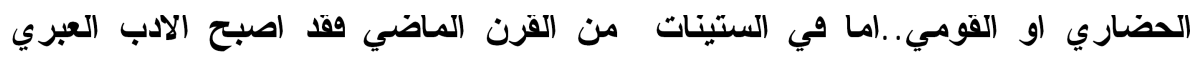

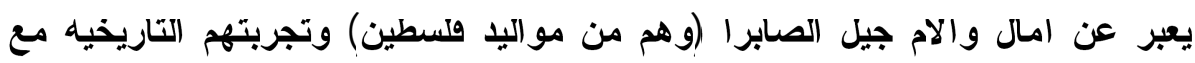
الاستيطان وراح يعالج مشاكل الاستيطان الإسر ائيلي بو بو اقعه ومكوناتها.. وبدايات الادب العبري كانت مع ظهور حركه الهاسكالاه اليهوديه إحركه التتوير) (.r).. و لاهميه هده الحركه وي نشوء اللغه العبريه والادب العبري وتطورهما لاحقا نشير إلى اتها اتخلت طابعا يتمشى مع الفكر اليهودي والثخصيه اليهوديه... وصد امتلت بين الستينات والسبعينات من القرن التامن عشر واستمرت حتى منتصف الربع الكيع الاخير من القرن التاسع عشر.. واهتمت هده الحركه باليهود وتطويرهم من جميع

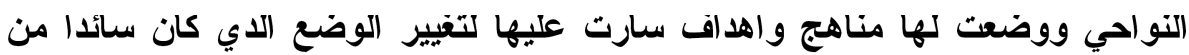

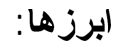

التورة على السلطه الرباتيه المطلقه في حياة اليهود (1).). القضاء على السلطه الرباتيه التي ورضها اليهود على اتقسهم في الجيتو ليخلقوا فيما

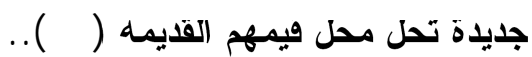


التوجه إلى اللفه العبريه والادب العبري الكلاسيكي وتجديد هاً بروح التقافه الاوربيه

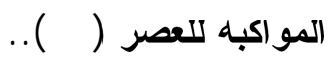

تحويل الدراسه العبريه من الدينيه إلى الدنيويه ودلك باستبدال دراسه التلمود باراسه التوراة والادب العبري بشعره ونتره وصياغه التعليم بروح العصر عن طريث

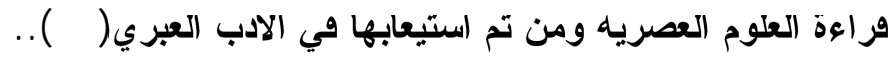

ومن الناحيه التاريخيه تعتبر اسفار موسى الخمسه اقلم النمادج الادبيه العبريه

التي يال اسلوبها ويناؤها على تاترها بالتشكيلات الحضاريه المجاورة: البابليه و الكنعانيه والمصريه.... الخ وجاء بعدها كتب الحكمه متل سفر الامتال وايوب وسفر الجامعه، والاثعار الاينيه متل المزامير والمراتي واشعار الحب والغزل متل نشيد الإنشاد.. ويرى بعض نقاد العهد القديم ان كتب الاتبياء داتها، رغم توجهها الديني و السياسي الواضح، هي اعمال الدبيه يتسم اسلوبها بالجمال (rO)...

اما الكتب الاينيه التي ظهرت بعد دلك فمعمها مكتوب بالعبريه المشوبه

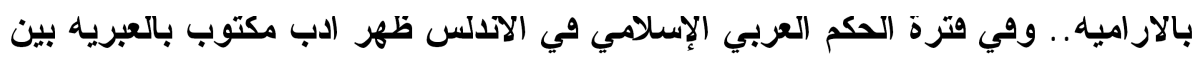

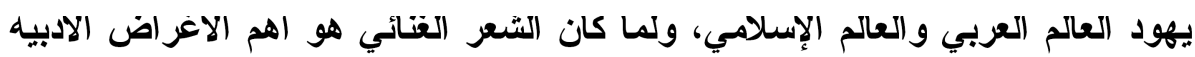
عند العرب وقد اتعكس هلا على الجماعه اليهوديه، وظهر شعر غنائي عبري متاتر وي اخيلته وعروضه بالثعر العربي.ومما يجدر دكره ان اغراض الثعر المكتوب بالعبريه

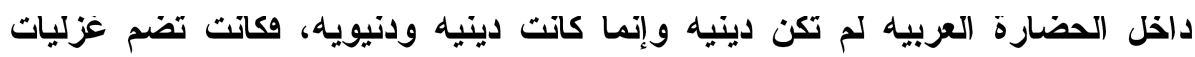
وخمريات وفخرا ووصفا للطبيعه، تم ظهرت انواع ادبيه اخرى بين يهود الحضارة

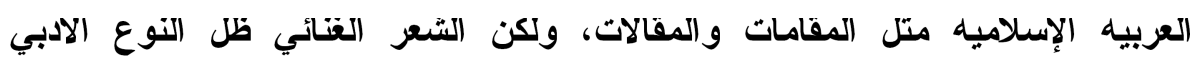
الاساسي (1)...

وضد ظهر في (يطاليا شعر غنائي مكتوب بالعبريه إبان عصر النهضه.. وكان عمانوئيل بن سولومون (عما نوئيل الرومي) هو الهم شاعر غنائي، وكتب سوناتات

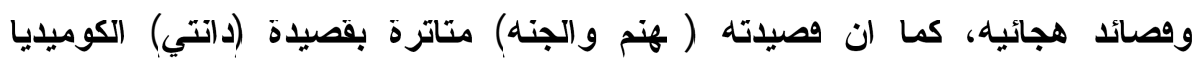
الإكهيه (MV)...

اما اهسام الادب العبري من حيث المنهج التاريخي ههي اربعه افسام حسب عصور كتابته: - (1) I. الادب العبري القديم: وير اد به الادب الدي كتب في عصر تدوين العهد القليم و التلمود والمشنا وشروحها.. 
r. الادب العبري الوسيط: وير اد به الإتتاج الادبي الدي كتب في العصر الوسيط وبصورة خاصه في الآدلس، ويعده مؤرخو الادب العبري العصر الدهبي لهـا الادب.. r. الادب العبري الحديث: ويراد به الادب الادي كوردو الادب الديزي مع بدايه عصر الاحياء القومي اليهودي في القرن التاسع عشر الميلادي.. ع. الابب العبري المعاصر: وهو الدي كتب مند خمسينات القزن الماضي بعد النداند

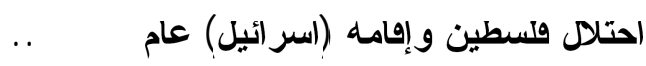
ونظرا لان الادب العبري المعاصر يعد امتدادا طبيعيا للادب العبري الحديث صي كتير من الثكاله وموضوعا ته وقل ارتاى الباحت، لاغراض هلاه الاراسد، ان يجعل

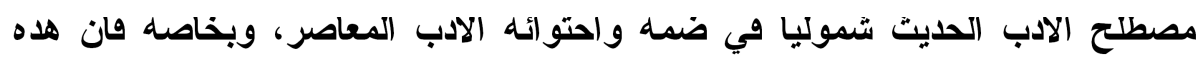

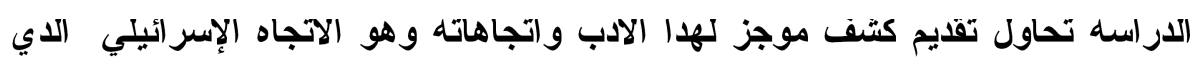

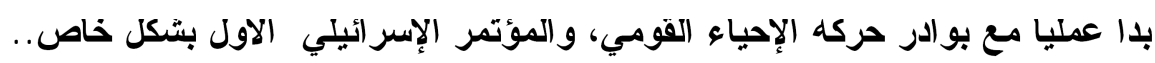

$$
\text { الحركه الصهيونيه والادب العبري }
$$

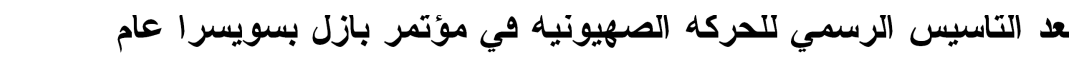

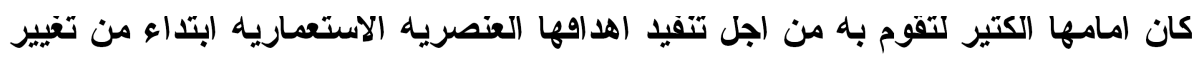
صورة اليهودي السيئه في تقافات الامم الاخرى، هخلق اليهودي الجديد المؤمن بالفكر

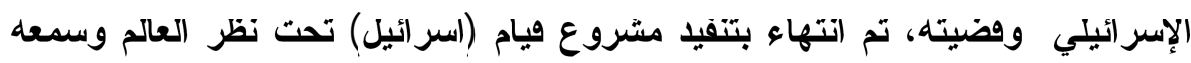

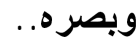

ويكاد يكون الادب العبري الاداة الاولى التي حملت رايه الدعوة الصهيونيه مند بداياتها التاريخيه الاولى، وكان بشكل عملي المصدر الاول لتاصيل الدعوة العقيديه

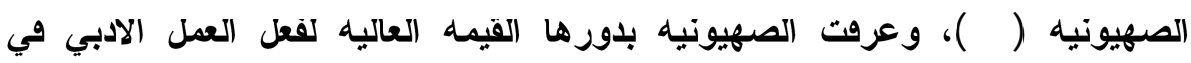
إيصال الدعوة والتبثير بالمنطلقات النظريه للحركه الصهيونيه، لم تال جها وي الإحادة من الادب العبري إلى ابعد الحدود، مدركه ان عمليه الإحياء القومي لن تبال حقيقه إلا

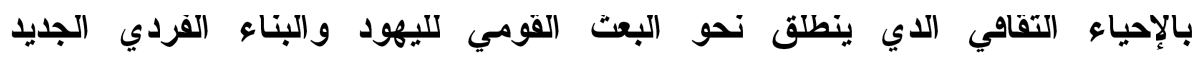

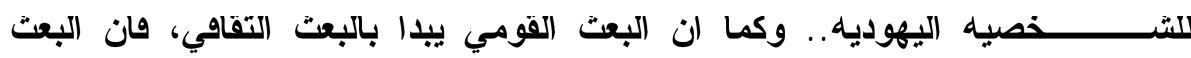


التقافي يبلا ببعت اللغه العبريه وإحيائها من جليد بعد ان اتحسرت عن الاستعمال ورونا طويله حتى كادت ان تصبح لغه غريبه حتى عن اليهود (تفسهم (9).). وهام الادب العبري وباتكاله التعبيريه المختلفه، التتريه منها والثعريه، بلوره كما خططت له الحركه الصهيونيه، وتتاول في موضوعا ته الاولى المجتمع اليهودي في الجيتو، و القرد اليهودي على مدى العصور واتصاله بالتقافات الاجنبيه المحيطه به، إلى لتى جاتب تتاول الترات التاريخي الروحي لليهود والتركيز على امجاده، تم ربطه بيهود العالم واوضاعهم الحياتيه التي طالما شكو ا من بؤســها وشقائها، وي محاوله منه لبعث الههم والسجايا وخلق اليهودي الجديا القادر على تتفيذ المهمه الاستعماريه للحركه الصهيونيه، بروضه اولا واقع الشتات وعزله الجيتو والاضطهاد المستمر الواقع عليه هي اوربا، تم الهجرة والاستيطان وإقامه وطن وومي يهودي في ولسطين على حســاب

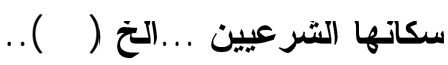
وياتي هلا كله لتوجيه النظر عن الفكر اليهودي الإسرائيلي نحو فلســطين،

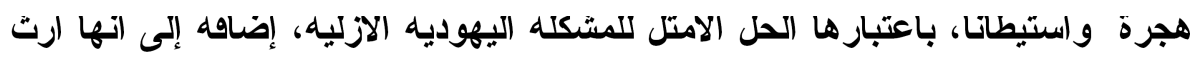

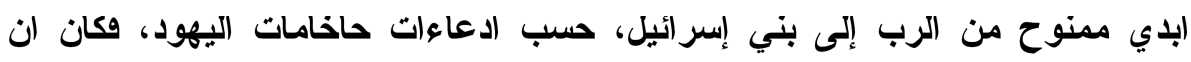
حقلت الاتتاجات الادبيه المختلفه بهره الموضوعات، والموضوعات الاخرى المتصله بها وكريا وعمليا كتصوير ولسطين ارضا خربه مهمله خاليه من السكان وان هناك والك

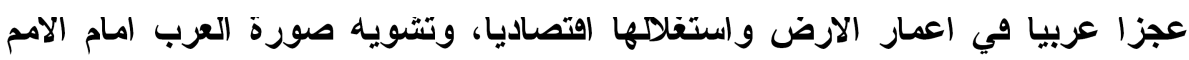
الاخرى في الووت الدي راحت هله الاتتاجات تمجد بما اسمته الدور الحضاري الموعود للصهيونيه في ارض فلسطين (II)... ولو اردنا ان نفهم اكتر عن مهمه الادب العبــــي في إبراز الدور الصهيوني،

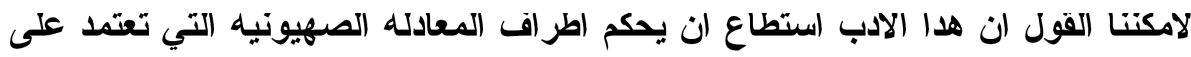
الداين والتراث في تحقيق رؤاها السياسيه واستطاع ان يربط بين الظاهرة اليهوديه التي لاني ولات تاريخيا في مكان ونشات في مكان اخر وانته، معنويا في كل مكان، لتظهر

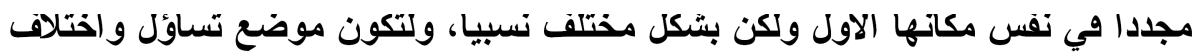
ولتشتبك وتتاخل مع مجموعه من العوامل والقوى، تختلف حسب الامكنه والفترات التاريخيه ولتصبح مجددا مشكله او ظاهرة تختلف عن غيرها من الظواهر والمشاكل الاخرى ... وهنا لعب الادب العبري دورا مهما في تسويه هده المشكلات وتبسيطها للعالم من خلال طروحاته واقكاره الصهيونيه التي لافت رواجا وفبولا لاى اوساط 
عالميه مؤترة واوجد القتاعه والحجه والتبريز لايهم بصحه الحلول التي طرحتها الحركه الصهيونيه والمتمتله، كما ولنا، بالهجرة والاستيطان وإقامه الوطن القومي في هلسطين وهي الحلول التي لم تعترض عليها هده الاوساط بل وايدتها وواقت عليها كمخرج لما سمي بالمشكله (لبهوديه وي حينه (بس).. لقد سخر الادب العبري نفسه مند بلايته لخدمه السياسه وممارسه التزوير وهلب الحقائق مرتكزا على احداث تاريخيه معظمها مزور وملقق ليبرر احداتا معاصرة

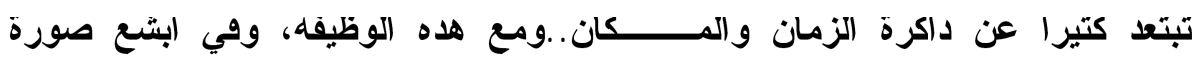
استخدم الادب العبري ايضا لخدمه اغراض عدوانيه: استيلاء مجموعات هجينيه على ارض شعب امن وعلى خيراته وممتلكاته وحقوفه وحرياته، مستخدما ابشع الوسائل، بالكدب والتلفيق وفلب الحقائق والمفاهيم لتضليل العالم عن حقيقه خطط هده المجموعات واهداوها (سب)... كما كاتت وكرة استخدام الادب كوسيله إعلاميه ودعائيه ود حظيث باهيه وانتباه اوليين في الترويج للفكرة الصهيونيه وإثاعه وعرض الجوانب المختلفه لاوضاع اليهود وي العالم واحوالهم المعيشيه المتنوعه ونواحي حياتهم السياسيه والاجتماعيه وغيرها بـا يدعو إلى الاتتباه وكسب العواطف واستماله الراي العام الإنساني باتجاه تاسيس احقيه صهيونيه وي النضال من اجل ترسيخ فكرة

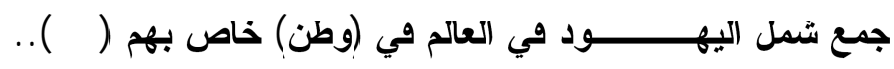
ورغم ان هده الغايه وائمه على مركب الخراهه والاكاديب التاريخيه والمغالطات القاضحه في المنطق والحقيقه والوفائع، إلا ان هدا الادب استطاع تقديم دلك كمبررات مقبوله لاى العالم الغربي وحقق في هدا نجاحا اكتر مما حقته الجهود السياسيه في تقيم الاسانيا التي ارتكزت عليها الفكرة الصهيونيه لتحقيق هده الغايه (10).. وعلى

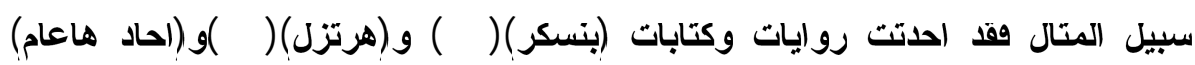
(N)(الادبيه على الصعيد العالمي اترا نقسيا لا تقل اهيه عن كتاباتهم السيـاسيه والإيديولوجيه.. 
ولسفه الادب العبري

يتضح مما تقام ان الادب العبري ليس ادبا إنسانيا بمعنى انتمائه الطبيعي والحر لتاريخ الادب في العالم الدي تتتجه مجتمعات فائمه لها تاريخها ومسارها الحضاري، بل هو ادب يضع نقسه وحوله شروطا مسبقه تعزله وتحلده ضمن إطار ضيق متعصب، وهو ظاهرة (دعوة) لها صفاتها العرويه و المعاديه للـتـاريخ، وصفاتها الاجتماعيه منبتقه عن تزييف تجمع ملقق يجري حقته باستمر ار بمجوعات بشريه دات انتماءات مختلفه متناهرة باختلاف البلان التي ولامت منها، وليس من موحد لها او جامع

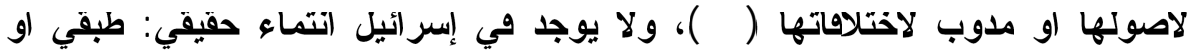
وومي او حضاري او تقافي بل هي محاولات مستمرة لتلفيق تاريخ مصطنع من وحدة واستمراريه وهيتين، ومتلما لا يمكن ان يكون لاي ادب القدرة على الاستمراريه ووحدة المسار التاريخي بعيدا عن وحدة المجموعه البشريه التي يعبر عنها هذا الادب، كللك فان الادب العبري، بثقيه الحديث والمعاصر، هو تجمع متنافر المستويات الحضاريه والاجتماعيه ومتعدد اللغات والتقاليل، وهده العناصر ملققه ومفروضه سلفا

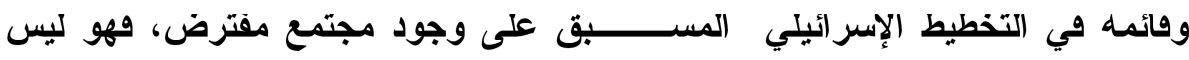
ادب مجتمع او ادب شعب وإنما هو ادب منبتق اساسا من اهكار عقائديه صهيونيه متعببه تقف وراءه وتثنكل ارضيته| - ع)..

لقد كان الادب العبري عند نشاته يقتقر إلى فاعدة اجتماعيه يركن إليها ويعبر

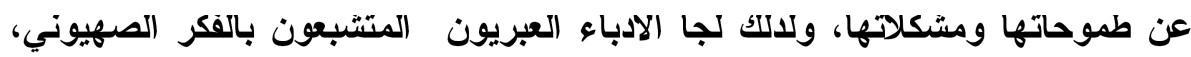
في معظم الاحيان إلى الاوتباس او الترجمه من الاداب الاوربيه او إلى معالجه وضايا

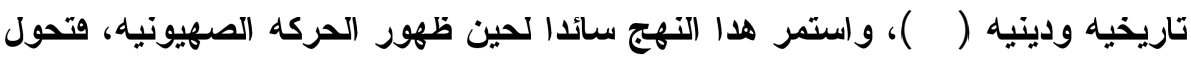

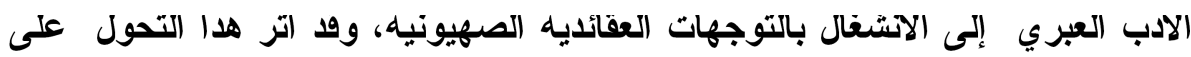
النواحي الفتيه والادبيه للعمــــليه الإبداعيه واققدها الكتير من سماتها الإنساتيه وتاتيراتها الوجداتيه (بr))، بل واصبح هلا الادب احد اسلحه الحركه الصهيونيه التي عملت على استــــــلاله ابشع استغلال لصالح الترويج لاوكارها ونتشرها بين اليهود

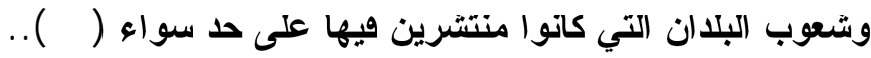
ورغم ان المركز العبري في ولسطين لم ينشط سوى في عشرينات القرن

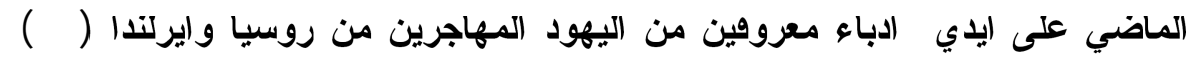


مها الفكر الاثتراكي والثيوعي الدي كان يلعو في ايديولوجياته وطروحاته في تلك التك الفترة إلى تفليب المشاعر الإنسانيه على التطلعات العرويه والعنصريه، إلا ان هؤلاء الادباء تخلوا عن تلك الاوكار التي سبق ان اعتنقوها او تناسوها، وبلالا من دلك تبنوا

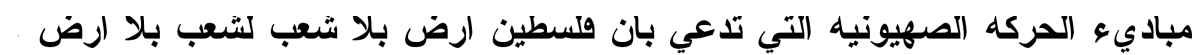

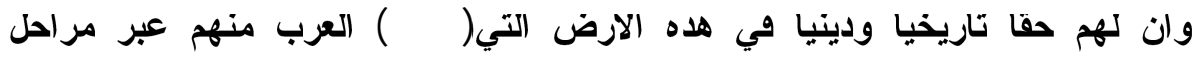

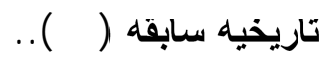

وضد اكلت المصادر العبريه داتها (1ع) انتغال الادب العبري بهـه المزاعم

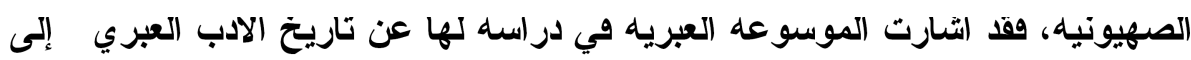

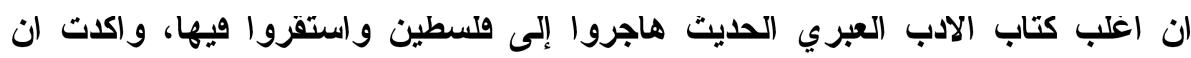

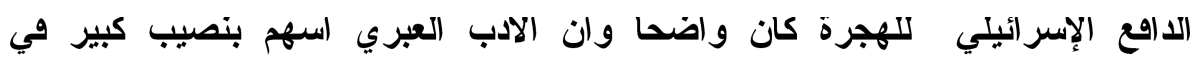

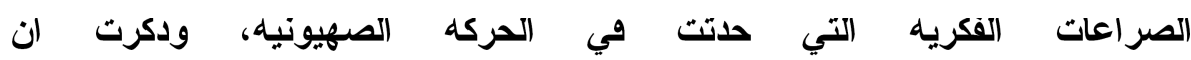

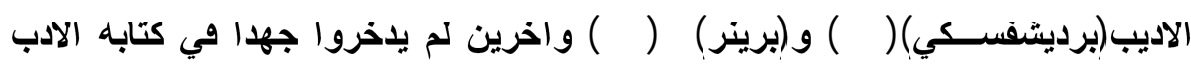
السياسي والاجتماعي متلما وعلوا وي كتابه الادب القصصي..

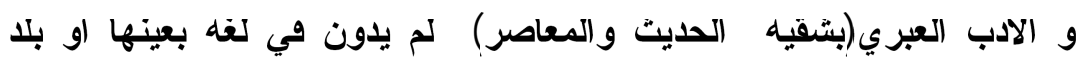
بعينه شانه في دلك شان الاداب الاخرى، ودلك لان اليهودي مند تشرده الاخير في القرن

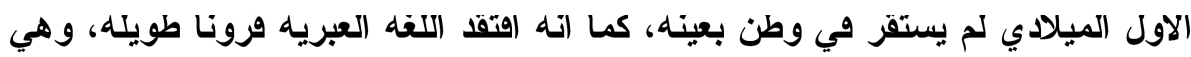

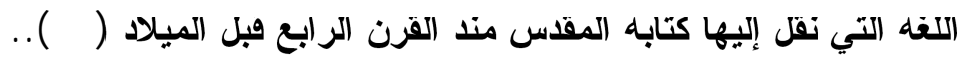

وكي تتضح الصورة اكتر عن فلسفه الادب العبري وملامحه نشير إلى ما ورد

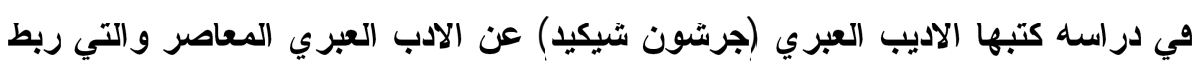
ويها بين مراحل تطور هدا الادب وكتابه وبين التاتيرات الادبيه والمدارس الفكريه العالميه التي تاتروا بها وانعكاس دلك على تحديد ملامح فلسفه الادب العبري واغراضه بثكل واضح ومنحها مميزات وخصائص محددة تكاد تختلف عن غيرها من القلسفات الادبيه (العالميه الاخرى ( - (0).. ف(أنيكيا) يرى ان الادب العبري في إسرائيل شكل خلا العقدين الماضيين امتدادا للادب الإسر ائيلي في الاربعينات والستينات من القرن الماضي، وتالف من اجيال 
بيولوجيه متباينه واتجاهات ولسفيه ومدهبيه متنوعل، اما الاجيال البيولوجيه وهي في اساسها تلاته، اولها من مواليا اواخر العقد الاول ومواليل العقد التاني من القرن الماضي، وتانيها من مواليا التلاتينات والاربعينات وتالتها من مواليا الخمسينات

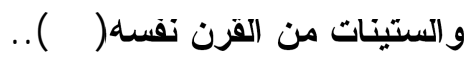

وينحر اهراد المجموعه الاولى من اباء هاجروا إلى ولسطين ضمن موجتي

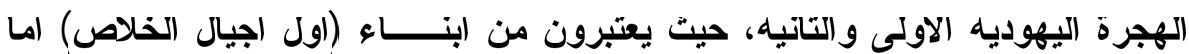
ابناء الجيل التاني وقل ولاوا ضمن المجتمع اليهودي الدي اخد يتكون داخل ولسطين بعد اغتصابها، وي حين ولا ابناء الجيل التالت في (اسرائيل) (Or)، وكانت التجارب الاجتماعيه التي صاغت الجيل الاول هي دكرى هجرة الاباء والرواد الاوائل والحرب

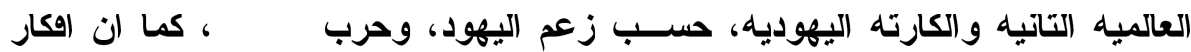
ها الجيل اورب ما تكون إلى الايديولوجيه الصهيونيه وفلسفتها، امـا الجيل التاني فاترت ويه حرب 1907 ومحاكمه ادولف ايخمان وحرب 197V، حيث تنطوي مؤلقات هدا

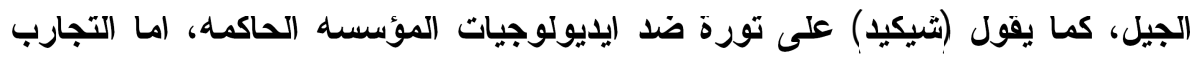
التكوينيه للجيل الاخير وكاتت حرب تشرين عام 19VYr والسلام مع مصر وحرب لبنان والاتتفاضه القلسطينيه (Or)..

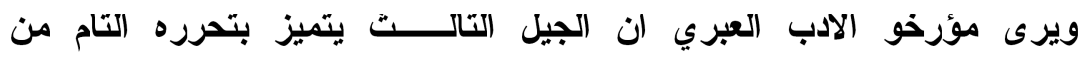

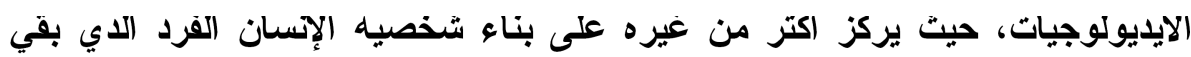

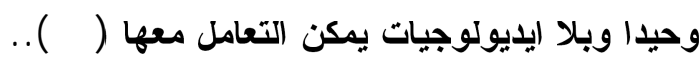

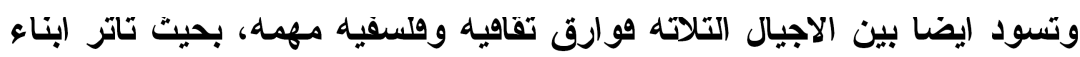
الجيل الاول بثكل رئيس بالادب الاوربي المترجم وولسفته بالإضاهه إلى الادب العبري

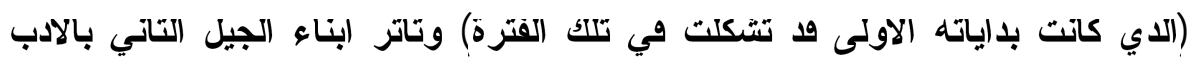

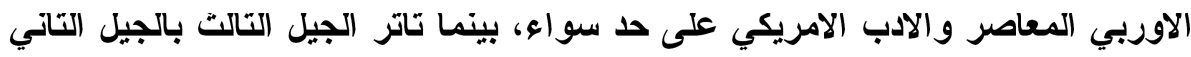
وبالتاتيرات الاوربيه الامريكيه والامريكيه الجنوبيه المختلفه أومنها ادب ماركيز بصورة

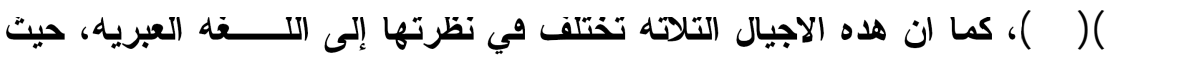
كان ابناء الجيل الاول يكتبون باسلوب راق رغم كونهم اول من كون اللغه العبريه الدارجه ويما مر ابناء الجيل التاني بمراحل الامج بين اللفه المحكيه واللفه المكتوبه، اما الجيل التالت ويعد بعضه إلى تقريب لغه الادب من اللغه الارجه،، ويتسم الجيل 
أ. عبد الوهاب محد الجبوري $[171$ [1]

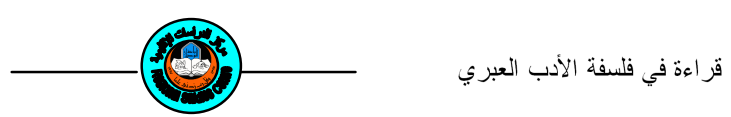

الاول بميسم الواقعيه ويما تميز الحاته الجيل التاني، امـا الجيل الاخـــير ويلاحظ ميله

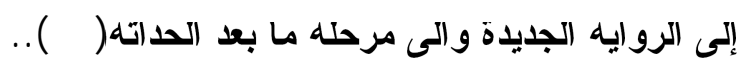

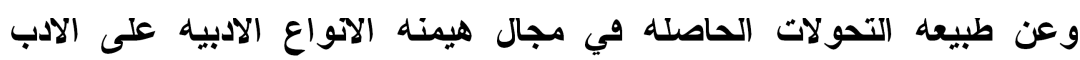

العبري وللسفته يقول شيكيد:(كان الشعر هو المهيمن ابان التلاتينات، ما عدا الكاتب عجنون، وي حين انتقلت الهيمنه إلى القصص في الاربعينات والخمسينات، وكاتت هناك

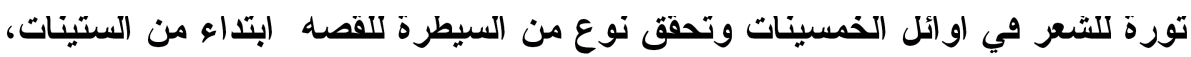
ونشات هيمنه القصه بالدرجه الاولى عن الحاجه الاجتماعيه إلى صياغه اهلاف تحلد قلسفه الإنسان وصورته وي اطر سياحات (جتماعيه ديناميكيه متغيرة) (OV).. ومن خلال متابعه الباحت لوجهات النظر الادبيه العبريه وما عبر عنه الادباء الإبه و الكتاب العبريون من افكار واراء حول التحولات وي الادب العبري وفلسفـته

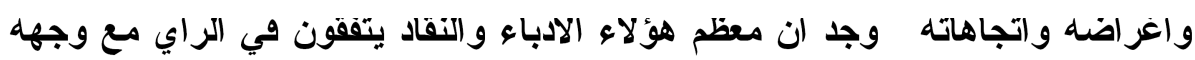

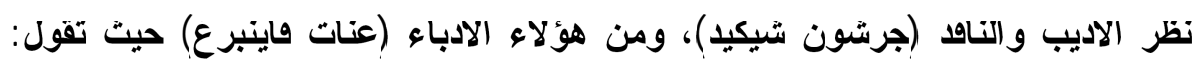
(مند العثرينات بات تتمو في إسرائيل اجيال من الادباء والثعراء جل إبداعهم او كله تقريبا انتج في ارض إسرائيل)(OA) وتضيف: (فسنوات العشرين والتلاتين من القرن الماضي هي سنوات هجرة وتجدد في الشعر الإسرائيلي)(09) تم تعود وتؤكد هيمنه القصه في الاربعينات والخمسينات وتقول: (وهي الاربعينات بلا الادباء بنشر إبداعاتهم

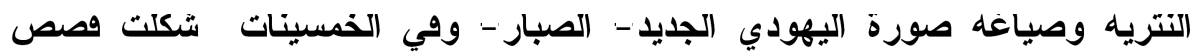
وروايات عدد من الادباء البارزين امتال موشيه شامير ويزهار، انعطاها في كتابه ابناء هدا (لجيل)( -7) وتضيف: (بلا الانقلاب الادبي في الشعر في عام $190 r$ وتبلور حول مجله لكرات - صوب او نحو - ونشطت حولها جماعه ادبيه وشعراء بارزون متل

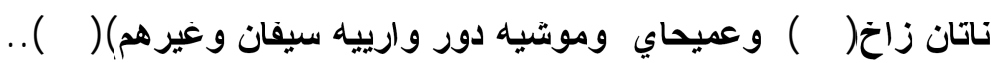

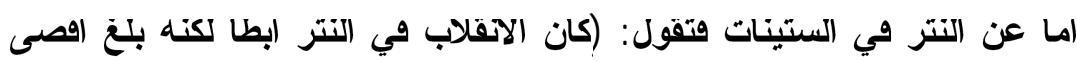

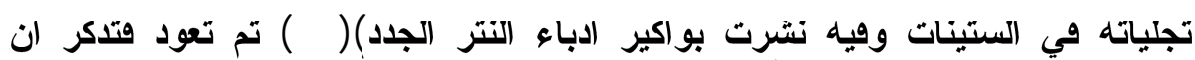
الكتابه الو اععيه وي القصه و الدراما العبريه حظيت بمرحله ازدهار متجدد وي السبعينات وامتاز النتر مند اواسط التمانينات بتعلديته وتتشطه.. 
لقد اعتمدت ولسفه الكتاب والادباء العبريون على استخدام موضوعات ومفاهيم واقكارا اساسيه كاتت وما تزال تمتل الإطار العام والمقومات الاساسيه للادب العبري/الإسرائيلي وهي داتها الموضوعات والاوكار التي يقوم عليها الفكر اليهودي/

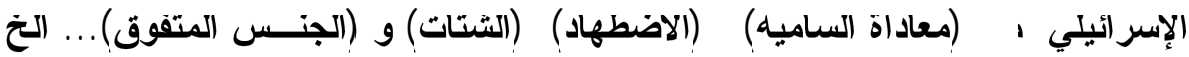
ودلك باستخلام ادوات ومفردات وظيفيه كتيرا ما تتردد وي الاعمال الادبيه العبريه متل: الكابوس، النازيه، غرف الغاز و المشانق... التخ (ع7).. إن ما يميز الابب العبري هو تحولات استخذامه لتلك المفاهيم والاوكار، حيث ان النظرة إلى الاخرين، او الاغيار، المستوحاة من الادبيات الاينيه والتراتيه اليهوديه،

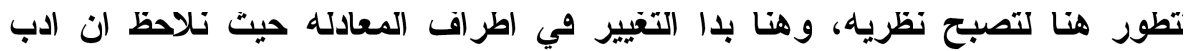
الجيتوات، الاي كان يؤكد على الاضطهاد والتقوق معا، يستمد من العهد القايم دواقعه وحوافزه ويعتمد على واقع الاوليات وي بعض الاماكن والظروف ويستعين بلغات الاووام التي كان اليهود يعيشون بينهم، نجد إن ها الادب ود تغير خاصه بعد تمركز الصهيونيه و اتساع نفودها، وبدا يقل من إظهار فكرة الاضطهاد مقابل تاكيد التفوق وبدا يعبر عن هدا الاتجاه باللغه التي كادت ان تموت، والتي لم تكن تستعمل إلا في الصلاة والطقوس لهن

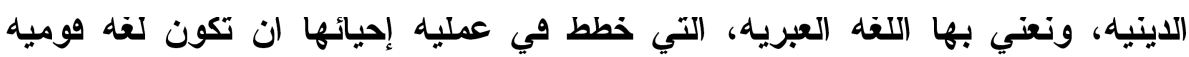

$$
\text { سياسيه بالدرجه الاساس (70).. }
$$

إن هلا التحول في نسب استخدام تلك الاوكار تثكل سمه اساسيه وي الفكر

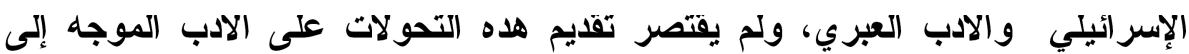
اليهود داخل إسرائيل وإنما امتد إلى كل الجاليات اليهوديه وي العالم، وعلى هل ها الاساس بدانا نتلمس وجود نوعين من الادب: ادب موجه إلى الداخل لا يظهر من هكرة الاضطهاد إلا بقدر محافظته على

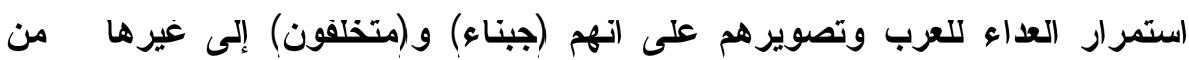
الصفات، وادب خارجي يراعي اعتبارات عديدة في مقدمتها إتارة عواطف الغرب من خلال وصف تطور اليهود وتفوههم مقابل ما ياعيه على السكان العرب، خاصه القلسطينيين منهم، من اتحطاط وعبوديه، ووي متل ها الطرح المضلل فاته ليس في وسع مارئ الادب العبري المعاصر، ما لم يكن على إطلاع تام بحقيقه الاساليب الصهيونيه، إلا ان يتيه وي مسار اتها المتعرجه و المغلقه (71).. 


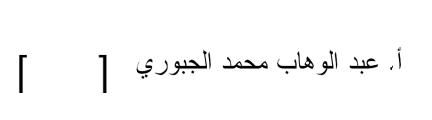

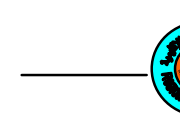

لقد تبنى الابب العبري، بسلوكيته المطروحه وغايته المنشودة القلسفه الميكاهيليه بكل ابعادها وتخلى عن واجبات الادب الضروريه كالحق والخير والجمال، كما لهادئه تشبع ايضا بالمقولات الصهيونيه الزائفه واعتمادها على الاساطير الدينيه المبطنه مند الباليه وراح يصطنع اساليب التعبير الفني عنها، هظهر الب لالروايه التاريخيه) الدي يسعى إلى إحياء الحياة العبريه القديمه وظهر الدب (التراث) الدي يسعى إلى تمجيد تراث الحياة اليهوديه في الجيتو باعتباره الحصن الدي وفى الشخــــــيه اليهوديه من التحلل و الدوبان (TV)، وظهر ما سمي بادب ل(النكبه) الاي يؤكد المعنى الغريزي لعقدة

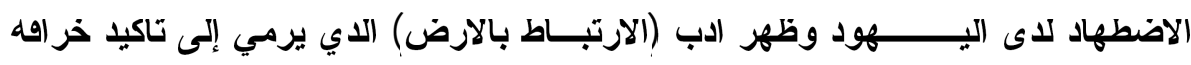

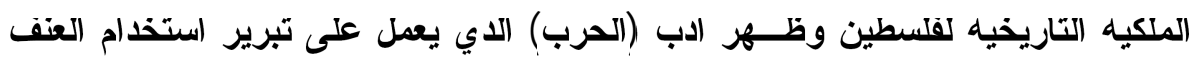

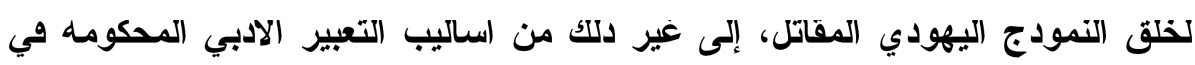
انبتاهها من الدعاوى الصهيونيه(7) (7).

واستتادا إلى هلا صان الادب العبري يقوم بضبط خطواته على جميع الجبهات

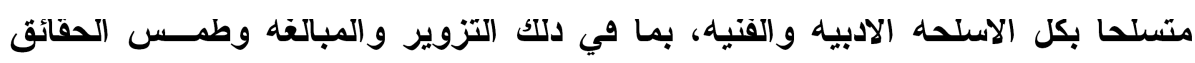
والحرب التفسيه.. الخخ وبالاستخدام الاتتهازي لاحداث الماضي في تبرير احدات جديدة

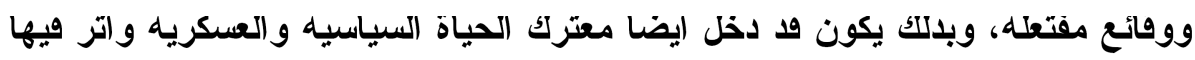

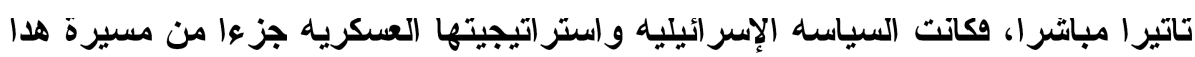

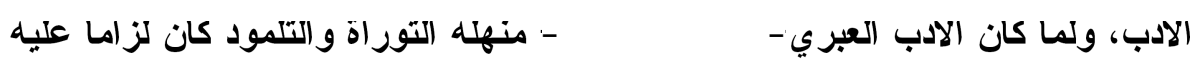
تبني ولسفتهما وي (بعادها الفكريه و السياسيه و العسكريه و الاينيه على حد سواء(79)..

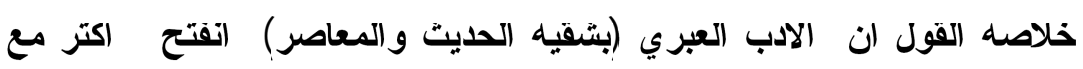
مسر السنين على اتجاهات وتقاليد ادبيه وولسفيه متباينه، حتى اصبحت التعدديه اليوم

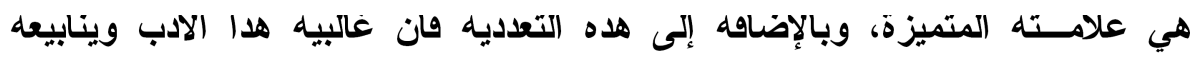

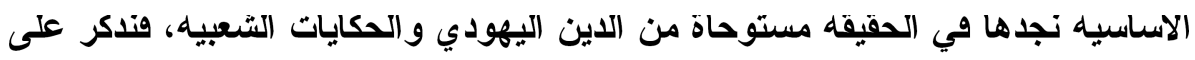

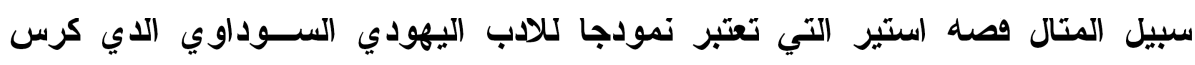

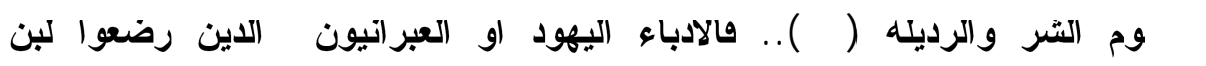


الصهيونيه، ليس في مقدورهم ان يخرجوا من بوتقه مبادئها التي تؤمن بتميز الجنس اليهودي، تغدي العنصريه وتدعو إلى تحقيق الغايه دون الاهـتقات إلى الوسيلهة..

$$
\text { نمادج من الاتجاهات الصهيونيه وي الادب العبري }
$$

بعد الإطلاع على فلسفه الادب العبري واتجاهاته الصهيونيه و والتي ابرزها:

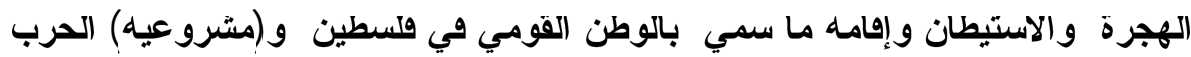
و العنف والاتتقام وإحياء اللفه العبريه وتثويه صورة العربي والتضليل والتعالي و التمييز العنصري والحقل والكراهيه إلى غيرها من الاتجاهات، فان الباحث يقام ويما ياتي نمادج مختارة من الثعر العبري تم اختيارها لتكون موضحه لهده الاتجاهات، وهي تبين التزام الادب العبري بالفكر الإسرائيلي وتحقيق اهداهه، تاركا الحديث عن الاتجاهات الصهيونيه كما وردت في القصه و الروايه والمسرحيه والمقاله إلى بحث

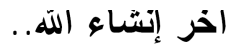

همن ابرز ما كتب في مجال التعبير عن الاتجاهات الصهيونيه في مجال الثعر هي وصيدة جامعه شامله للشاعر (نتان زاخ) تحكي فصه الاستيطان ومكوناته الاساسيه: الشعب، الارض، الفكر، العمل، البناء، الليل والتهار والحياة... الخخ وكل هله الامور تحكهها وتحددها وتقرر مصيرها الحرب التي هي جوهر الاستيطان الإسرائيلي ومستقبله كما يقهم من هلده القصيدة التي اســماها الثــاعر (مقدمه لقصيدة) (VI) هيقول: (هده القصيدة تروي فصه بشر/ بما يقكرون وما يريدون/ وهي (يضا وصيدة عن

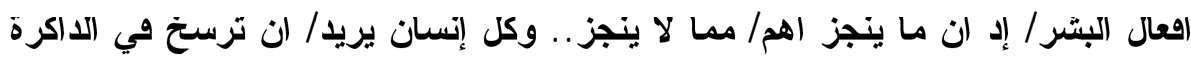

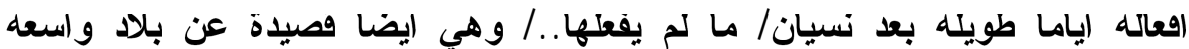

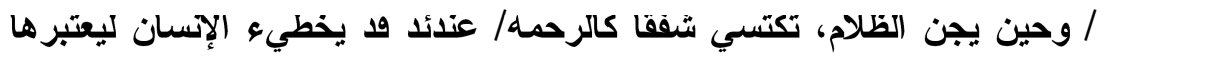
صحراء../ إدن هي وصيدة../ عن صحراء وعن بثر يمشون على رمال رمضاء/ تسري وي دمهم.../ وهي هصيدة عن كل ما يتعلق بالبشر/ كيف يشعرون حين تنشد

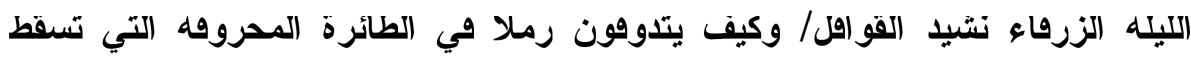
وتفنى/ كقصاصه حب ملتهبه.. وعوضا عن الكلام، وهي وصيدة/ عن منازل تهدم

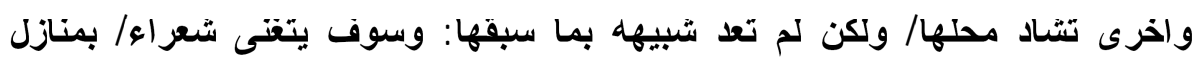

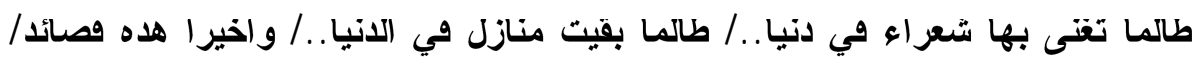
عن حرب كتبت في خضمها على مكتب دون سلوان...).. 
والاغنيه التي مازالت تتردد وي إسرائيل عن الحرب والتي كتب كلماتها الاديب

العبري والمسرحي المشهور (حانوخ ليفين) بعنوان لأنا وانت والحرب القادمها) (VT) والتي تعكس إحساس اليهود باتهم يعيشون في حاله حرب دائمه او وي انتظار حرب لتوني هادمه تقول كلماتها: (حين نتنزه نكون تلاته/ انا وانت والحرب القادمه/ وحين نتام

$$
\text { نكون تلاته/ (نا وانت والحرب القادمها).. }
$$

ومن النمادج الادبيه العبريه التي تروض اي محاوله للسلام وترى فيه خدعه مبررة هي صصيدة (حصار السلام) (VM) للشاعر (حاييم حيقر) حيث يقول: (لتنكن

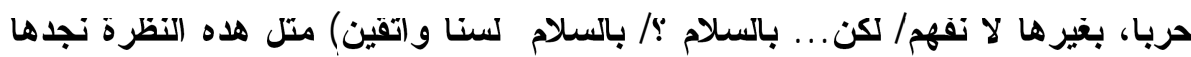

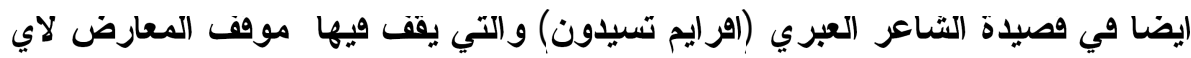

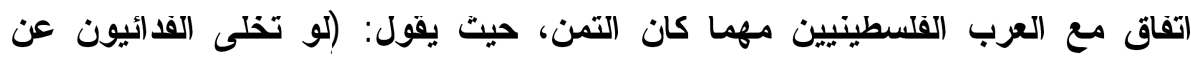

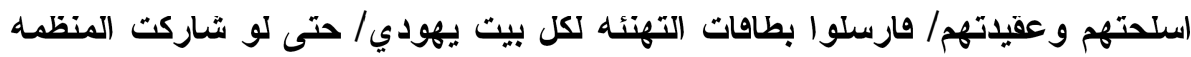

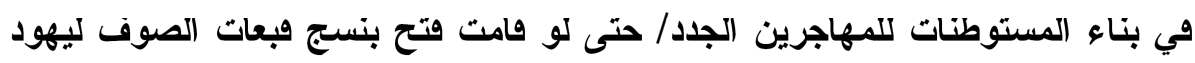

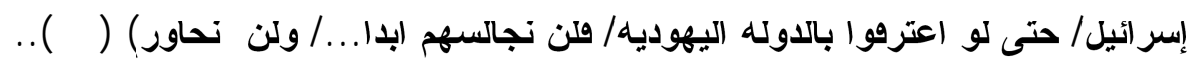
على صعيد اخر يكتسب العنف عند الكتير من الادباء اليهود درجهاه الشرعيه الداينيه الحتميه القدريه بالنسبه لليهود، ونجد الشاعر (حاييم نحمان بياليك)(V0) يظهر لونيل

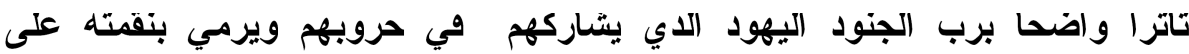

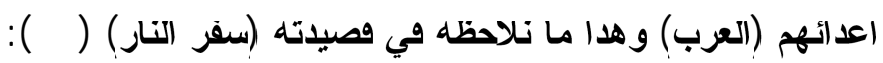

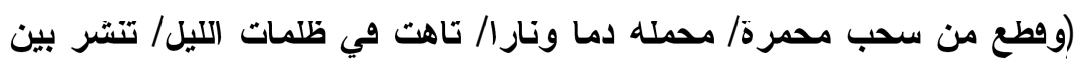
الجبال البعيدة غضب الهه النقمات/وتروي سخطه بين صخور الصحراء/ ويحل وزع الله على الجبال البعيدة وتسيطر ووة على صخور الصحراء الغاضبه/ يا اله النقمات، يارب،

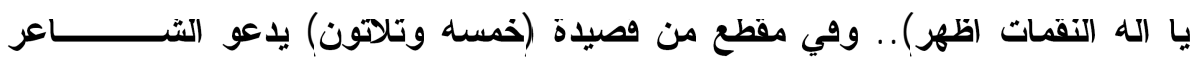

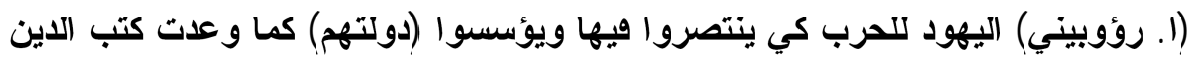
والتزرات اليهودي، ويقول: (كيف سقط ابطال إسرائيل/ كيف سقطوا ويسقطون شجعانا

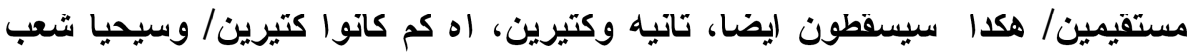
إسرائيل ولن يموت/ وسيجدل (ساساته/ شعب حر على ارض (بائه)(VV).. 
ويعمل الادباء العبريون على ربط اعمال اليهود وحروبهم وانتصاراتهم باسماء الآبياء او باي شيء يتعلق بالدين ودلك وي إطار منهجم التضليلي لإفناع اليهود و العالم بشرعيه هله الاعمال وعلى انها مؤيدة من فبل انبيائهم، حتى ان موسى إعليه السلام) يشاركهم في الحرب ويقاتل اعداءهم العرب الدين سرعان ما يهربون من

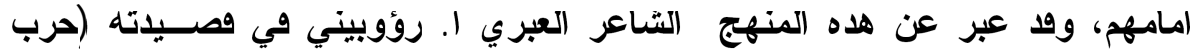
القدس) التي يقول فيها: (تسلقوا، اغاروا، رموا على البيوت/ ايديهم في القتل والسلب/ عندها نهضت يمين موسى/وامتدت من اليمين../ هشقت جمجمه بني إسماعيل/ فاجات (الصدمه ولبهم/ هربوا من المدينه بسبع طرق) (VA)..

ومن المضامين التي عنى بها الشعر اليهودي، الاتتقام.. همعروف ان لزعماء لزعاء

اليهود اسلوب خاص في معالجه وضاياهم يتلخص في تلكك المقوله الشهيرة لإداويا بن غوريون): (لا يهم ما تقوله الشعوب الاخرى، بل المهم هو ما يقعله (اليهود) (V9)..

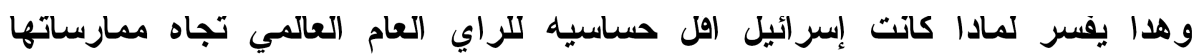
العدواتيه نحو العرب.. وضد اشار د. ودري حنفي في كتابه (الإسرائيليون.. من هم ؛)

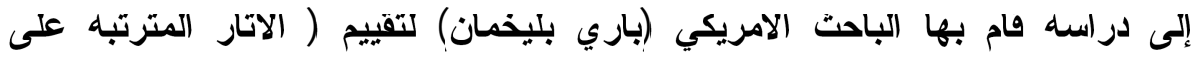

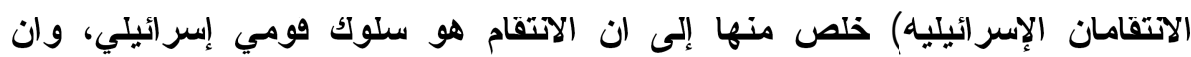

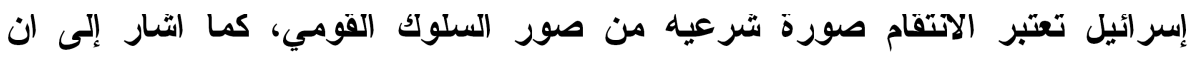

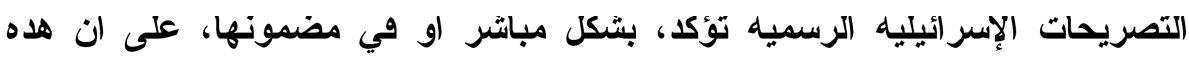

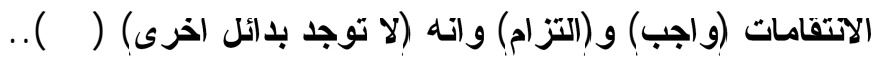

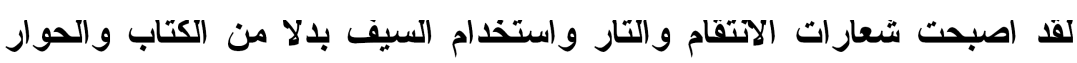
هي الشعارات التي ما زالت تتردد كتير ا في الشعر العبري، وفي هصيدة إشاؤول تثرنيخو صكي) (AI) بعنوان (ليكن هلا تارنا) تعبير عن حقد مسموم لا يمكن لاي إنسان وهمه او معرهه كنهه سوى اليهود انفسهم وهو تعبير (يضا عن إحساس بالآم يستلب من صاحبه إنسانيته ويعمق من كرهه وحقده للاغيا ر (غير اليهود) ويقول:

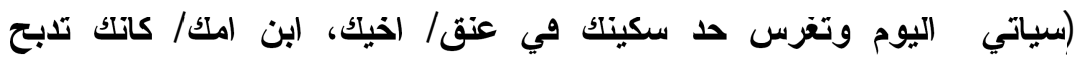
خنزيرك المفضل/ في عيد القيامه، وي الفناء او وي ميدان القريه/ وسيكون رنين انات موته متل الموسيقى او المهرجان في ادنيك المتلهفتين/ يا يوم التار) (Ar)...

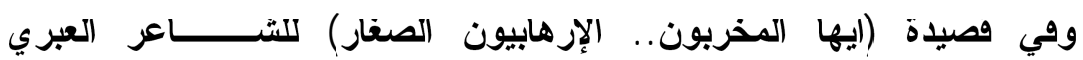
(ابشلوم كور) نجد ان المنطق النازي يتحكم وي مضمونها ويقرن الثاعر القتل بالاتقام 


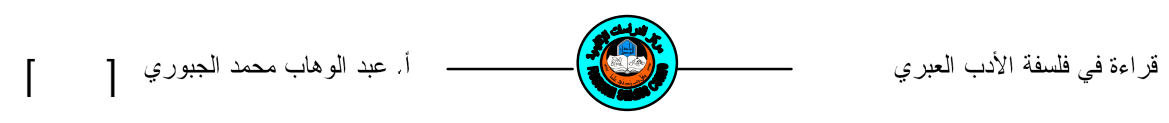

ويقرن التوسع امتتالا للاسـاطير التوراتيه، ويقول: (توصلتا إلى نتيجه/ انتا يجب ان

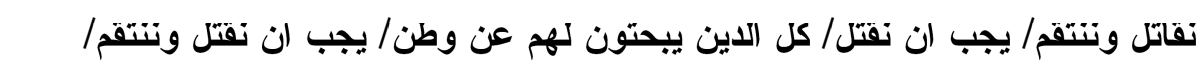
يكون لنا وطن/ من النهر إلى النهر) (Ar).

والمتتبع لصورة الاتتقام صي الادب العبري لوجد ان لهذه الصورة بلدايات تعود

إلى هترة الجيتو في القرن التاسع عشر، وفي العقود الاخيرة من هلا القرن ظهرت مفاهيم ووميه مبنيه على الروح اليهوديه وساهم الادب العبري وي التعبير عنها من فن خلال محاوله تصوير حال اليهود الصعب هي اوربا واضطهادهم المستمر نسبيا وبصورة خاصه في اوربا الثرويه.. وبتركيز الاب العبري على الاضطهاد الموجه ضد ضل البهود واستدكاره لما يسميه (الإرث التقافي اليهودي) حاول هدا الادب إيجاد (الامل الإنل (القومي وبعته من جليد). واول ما وعله الادب العبري في هلاه المجال هو توسعه في وصف الحاله

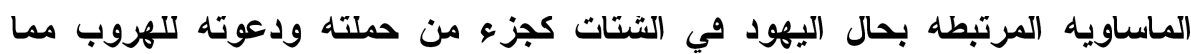
يسميه عالم الاضطهاد إلى عالم ارحب واوسع، وبدلك هيا الادب العبري اليهود ودعاهم

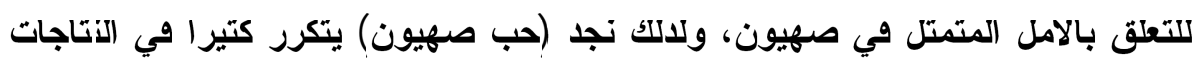
العبريه لتلك الفترة، وعلى التوازي مع هلده الدعوة ركز الثعر العبري، كبافي الاغراض الادبيه الاخرى من فصه وروايه ومسرحيه ومقاله، على هكرة تميز اليهود عن بافي الامم وعلوهم عنهم وصارتهم على البقاء رغم ما يتعرضون لله من اضطهاد وتتشت...

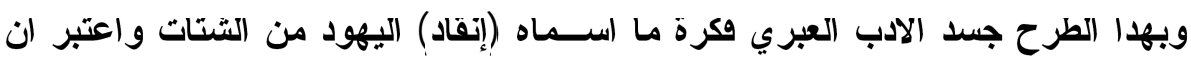
(حلم الإنقاد) سيتدهق عندما يكون اليهود مهياين لدلك وراغبين ويه.

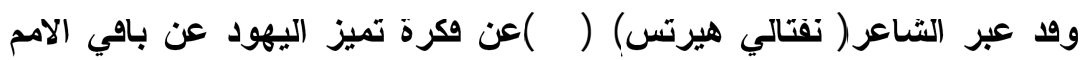

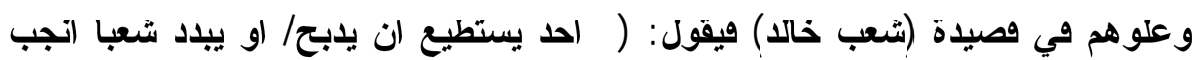

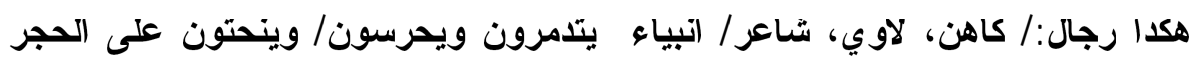
وصايا الرب العشر المقدسه)(10)... اما الشاعر (لديقيد وريشمان) (AT) وقد تحدث عن فكرة إنقاد اليهود من الثتات في صصيدة مطلعها: (عندما يولد جيل جليد.. ويكبر/ جيل سيفهم معنى الإنقاد/ يرغب، 
يشتاق ويهييء لده/ عندئد سيتم إنقادك/ عندئد ستتق).. وهام الادب العبري فبل احتلال قلسطين عام I9عA بتشجيع المهاجرين اليهود إلى فلسطين واستعمارها وحتهم على

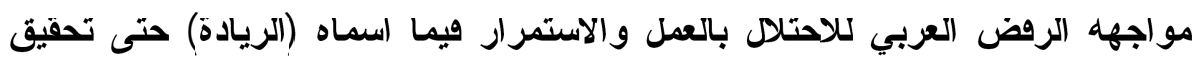

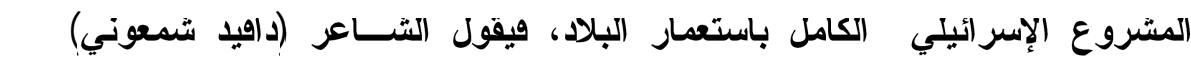

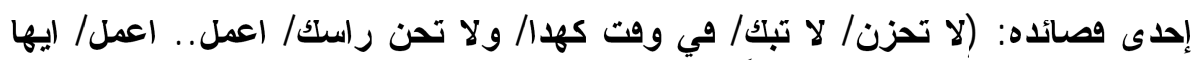

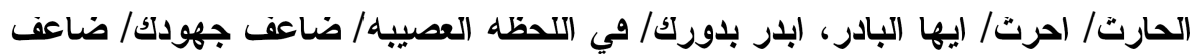

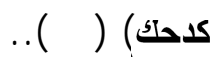

ومي ظهور موضوعات جديدة يتحلث عنها الادب العبري في ايامنا هلده نتيجه للاحدات الكبيرة التي هزت الوجود الاستيطاني اليهودي بخلاف الادعاء الإسرائيلي

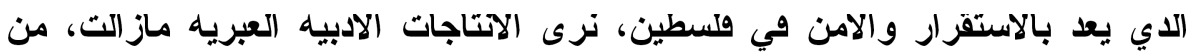

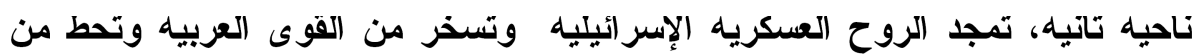

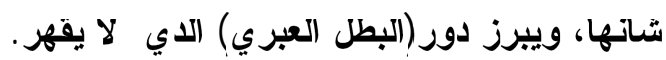

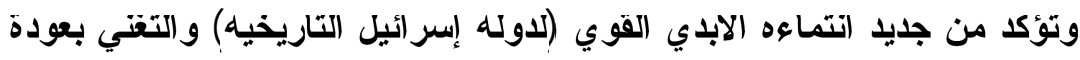
العصر الدهبي لاورشليم الموحدة وباتتصار (لداود المقاتل اليهودي) الدكي التحيل الديل الجسم على جوليات العملاق اللاسامي وبتجريد الارض التاريخيه وعودتها إلى حيازة اصحابها (MM).. وها الثاعر (العبري (أديدي منوسي) (19) يكتب عن بطوله (إبنيامين

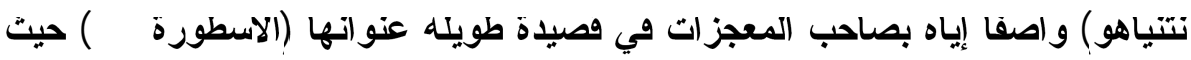

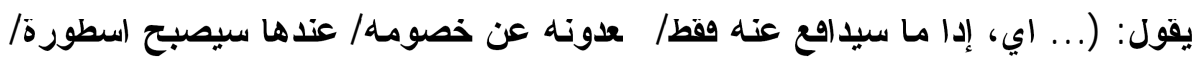
نتياهو صاحب معجزة)( - (9)..

وهناك نمادج ادبيه كتيرة تتحدث عن بطوله الجندي اليهودي الاي يعتبر، حسب القلسفه اليهوديه، الاولدر على استخدام السلاح لاته إيتمتع بتقوق عقلي وبلني خارق) ولا يعرف الضعف الإنساني في ساعات العمل، وهو حسب هده القلسفه إنسان

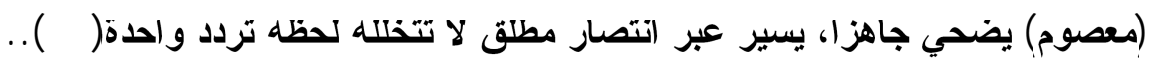

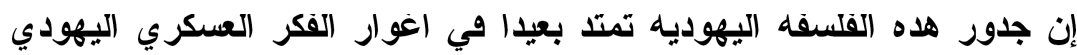

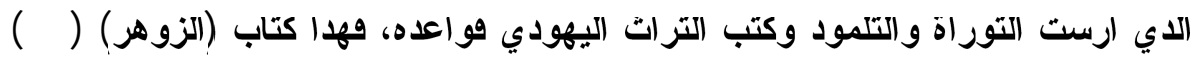
يبين نوعين من القوى (القوى المتدوقه من الكائن المطلق، من ناحيه اسلوب وطبيعه

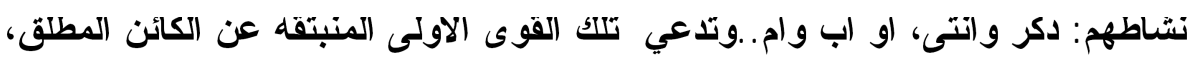




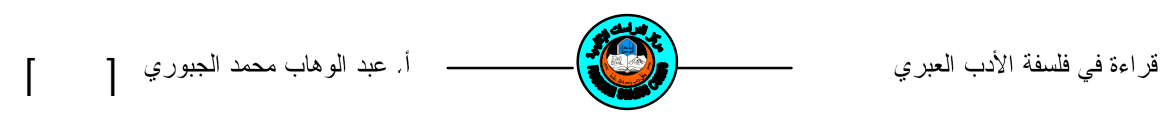

الحكمه والقهم.. وهد اتبتقت من الحكمه العطف ومنه الخــلود ومنه الاســاس،

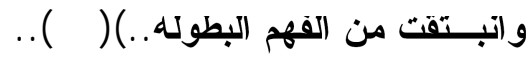

وفي تعبير مباشر عن (القدرة الخارفه للابطال اليهود) والادعاء باتهم قادرون

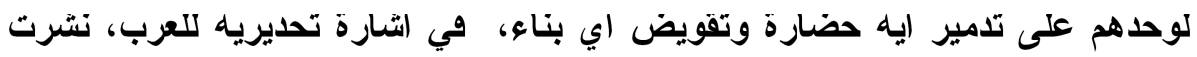

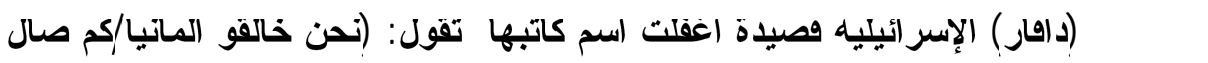

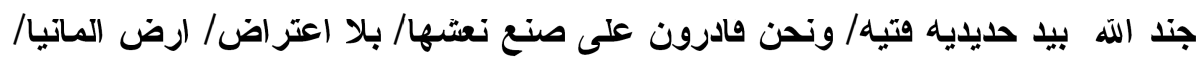

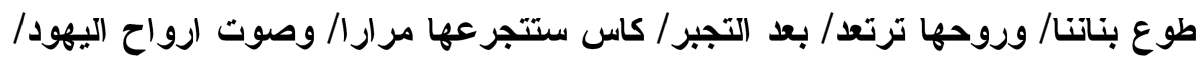
سيقف عاليا/ باستمر ار)(ع)..

ويعبر الشاعر إيهودا عميحاي) وي هصيدته (اليهود) عن غطرسه جوفاء وحس

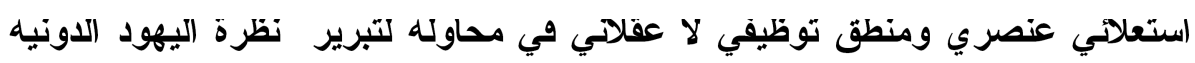

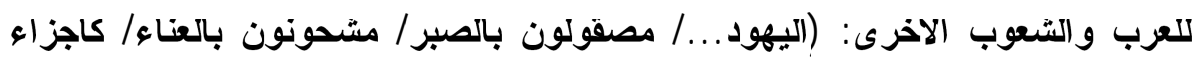

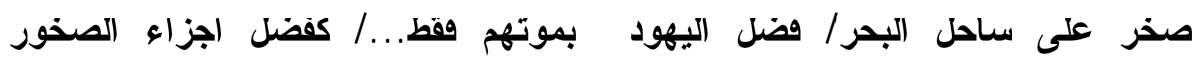

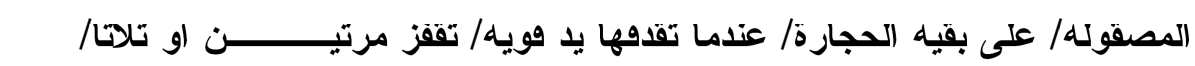

وجه المـــ/ وبل ان تغرق...) (90)

وهدا الشاعر إ(ايم سيدون) يشيد كتيرا بالمهاجرين الجدأد والدين سيصبحوا

جنودا وي الجيش الإسرائيلي ويصف صورة (المستقبل المشرق) التي سيصنعها هؤلاء الجنود للشعب اليهودي، ويقول في وصيدة إسله الاستيعاب): (هم جاعوا لمنح الاطفال

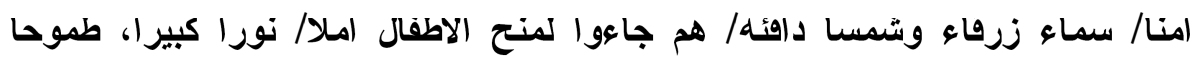

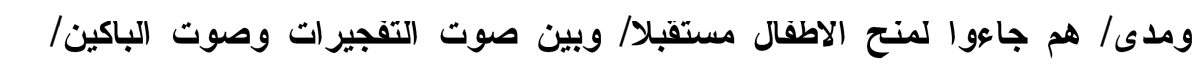
مزيد من الرواد والمهاجرين/ ايرنه وإيليا ويوليه تحولو// إلى اسماء إسرائليه)

وهي وصيدة (إلى العصفور) للشاعر (بياليك) شكلت فلسطين والعودة إليها

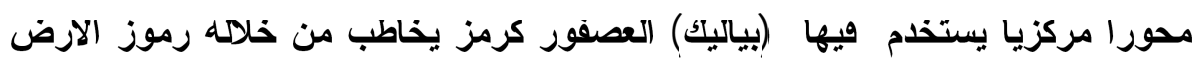
المقدسه ويطلب منه ان يخبره عن امجاد الارض القايمه وما تحتويه من دلالات دينيه

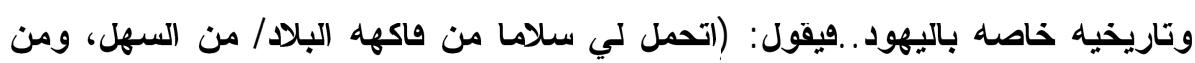


الوادي، ومن ومم الجبال/ ووادي شارون وتل اللبونه/ وكيف حال الاردن ومياهه (الصاهيه ؟!/ كيف حال الجبال وكل التلال) (9v).. ويبلغ التضليل الإسرائيلي مداه في هده القصيدة عندما ياعي الثشاعر ان قلسطين هي ملك وارث ليهود.. ويقول: (غردي عصفورتي.. لارض فيها وجد/ ابائي

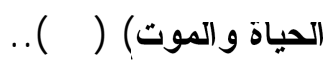

اما الشاعر (أشاؤول تشرنخوفسكي) وقد كتب هو الاخر عن موضوع الهجرة

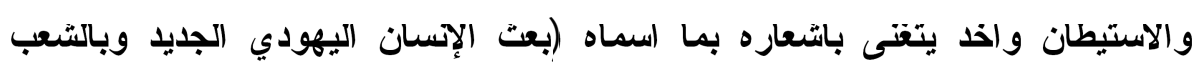

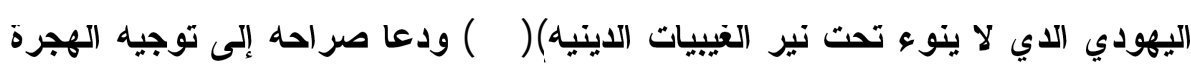

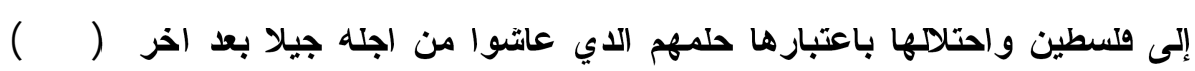

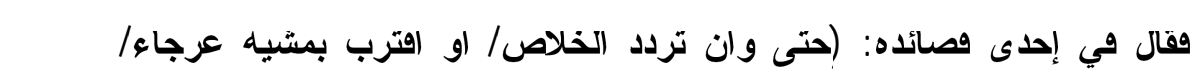

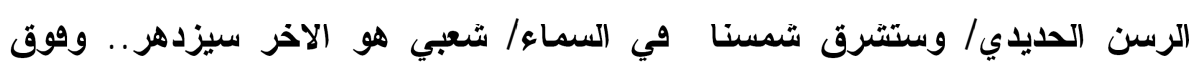
الارض سيظهر نشوء جديد/سيالي بالسلاسل التي تغل يديه وسيرى النور امام عينيه/

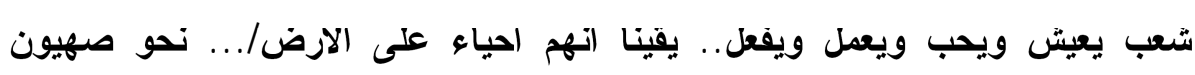
وجهوا راياتكم، يا (بطال يهودا) (1 - ()... اما عن صورة العربي في الادب العبري وقد اتبعت الحركه الصهيونيه استر اتيجيه واضحه المعالم ترمي إلى تشويه صورة الشخصيه العربيه لتبرير كراهيتها مستخدمه وي دلك اساليب النمطيه او القولبه للعرب وولإسقاط الصراعات الثخصيه

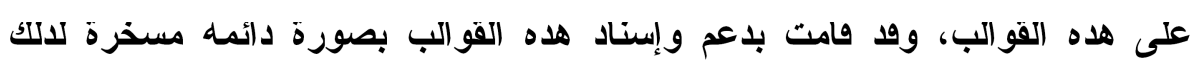

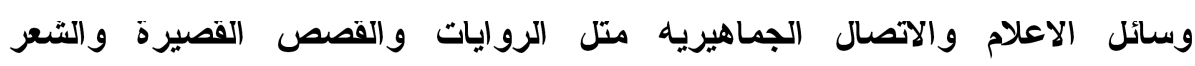
و المسرحيات والصحف والاشرطه السينمائيه والإداعه و والتلفزيون، وهد اسهم هلا ولته

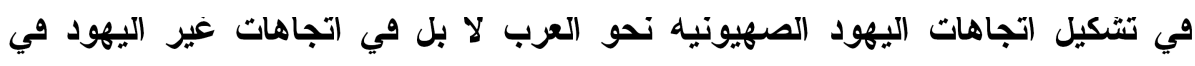

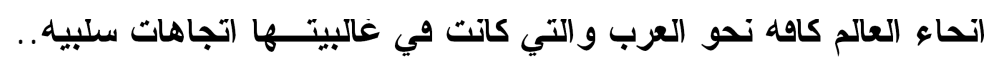
وبناء على هله الاقتراضات بدات الحركه الصهيونيه برسم سياستها الاستيطانيه وتنقيدها وي ولسطين مجندة بللك الادب العبري إلى جانب الوسائل الاخرى لإيجاد

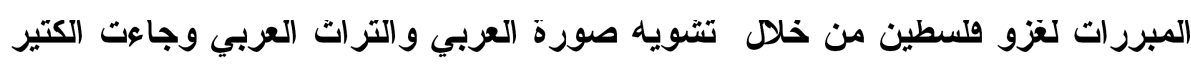

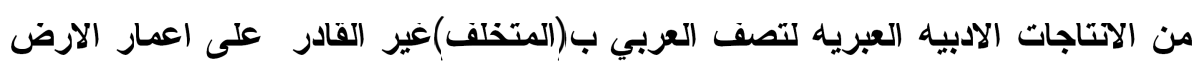

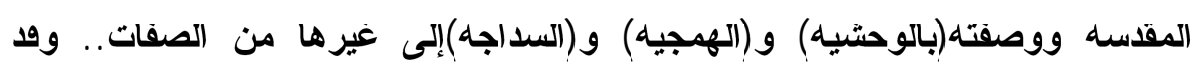
انطلق معظم هله الكتابات من الاهتراض الدي روجت له الصهيونيه في بلايه تاسيسها 
قراءة في فلسفة الأدب العبري

و الدي يقول بالتقوق العروي اليهودي تجاه العرب البدو المتخلفين (م - ()، وليس غريبا ان يتسم تفكير الادباء اليهود والمستوطنين على حل سواء بهاد السمه، لالك الكي

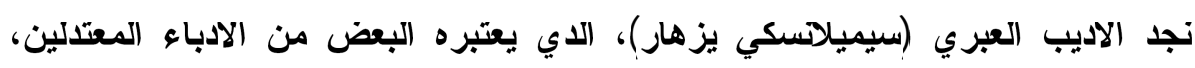

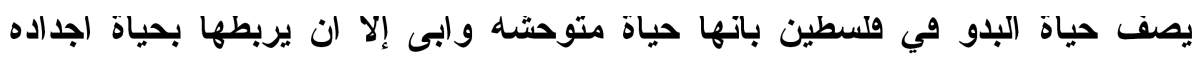

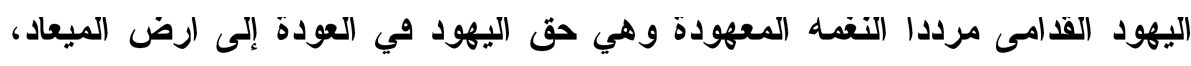

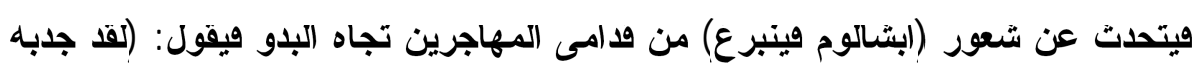

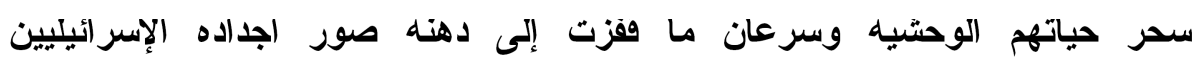

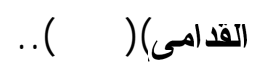

وليس هلا وحده هلقد شكلت الخلاهات التي ووعت بين العرب واليهود، على امتداد عقود طويله، المعين الدي مازال الادباء العبريون يغتروهن منه موضوعاتهم

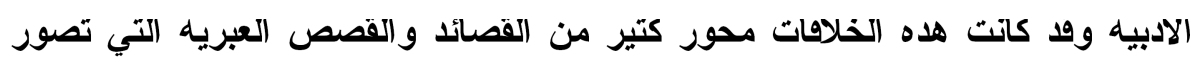

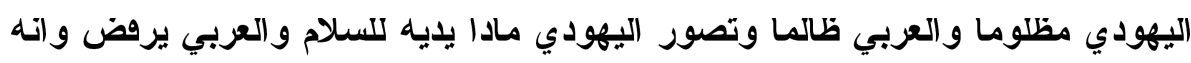
دائما يلجا للسلاح ويستغل ضعف الإسان ويحترم القوة وان العربي إدا احترم إنسانا

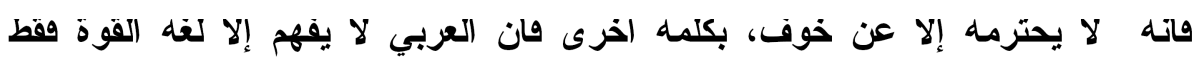
..) ( 1 - ع)

وهناك انتاجات ادبيه عبريه اخرى صورت العربي في ابثع صورة وبينت ان

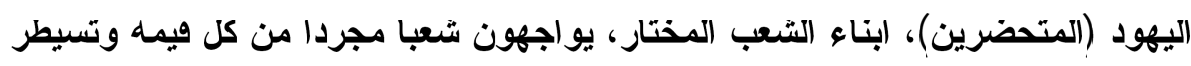

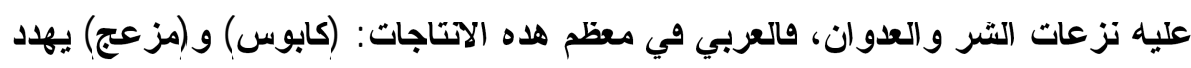

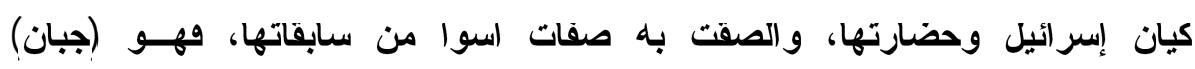
و(خبيث) و(مكار) و(صدر) و(متعطش للاماء) إلى غير دلك، وهدا التصوير يعكس حقيقه النظرة اليهوديه للعرب وي كل زمان ومكان..

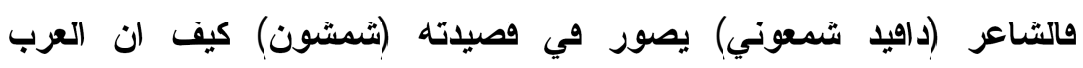
يتطاولون على اليهود ويتكبرون عليهم على الرغم من ان (الههم ليس مقدسا) كاله

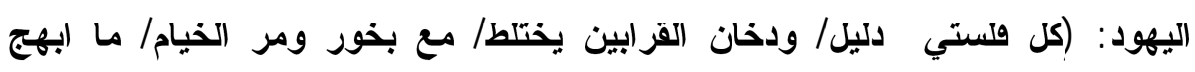
(الدفء مـع الاغاني/ لو يغتي شمشون اغانيه) (0 - (1).. 
وفي مرحله السبعينات والتمانينات وصف الادب العبري العرب بصفات تسمهم

بالعجز وفي الجواتب النفسيه والعقليه ووصف زعماءهم بالوحشيه والههجيه ووي بعض الاحيان بالجنون.. واخطر ما في التضليل الادبي الإسرائيلي هو سعي بعض الادباء اليهود إلى ربط العرب بالنازيه واتهم متعاطقون معها واستنادا إلى هلا بنوا استتناجاتهم بان العرب هم ضد الساميه يتسمون بالتعصب وعلدم التسامح وبان الكراهيه توجه سلوكهم.. كما يصف الادب العبري العرب ايضا بان لايهم شعورا بالكراهيه العرويه ليس ضد اليهود وحدهم بل ضد كل الاهليات التي تعيش بينهم كالاكراد و المسيحيين وغيرهم وان هله الاهليات لا تثعر بالامان و الامن معهم (T - (1).. إن الهذف من طرح هله الاهكار في الكتابات العبريه، حسب راي الباحث، هو تبريز إهامه ل(الدوله العبريه) التي يجب ان تقتصر على اليهود وحدهم وحيث لا مكان

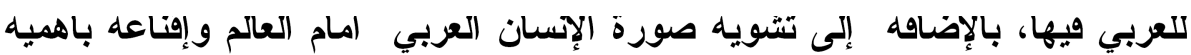

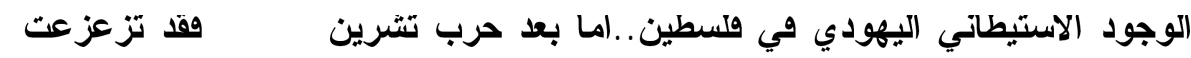

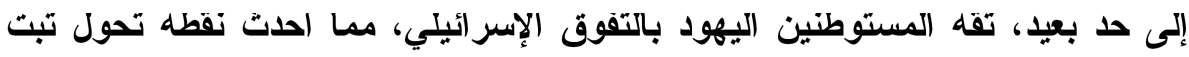
هيها ان النصر غير مككن ان يكون حليف إسرائيل إلى الابد، وعلى اتر دلك ظهرت اصوات الدبيه عبريه تتسم بثيء من العقلانيه والاستعداد لقبول وجهات النظر العربيه من امتال (عاموس عوز) الاي تحول من يميني متعصب إلى مشارك في مظاهرات

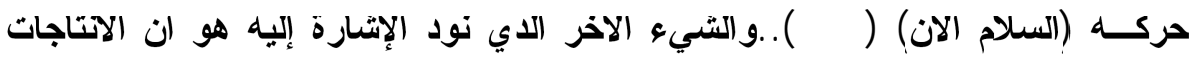
الادبيه العبريه ود انعكست على الاتجاهات الفكريه والتربويه للاطفال اليهود وشبابهم واسهم في تحول الكتير منهم إلى اليمين المتطرف.. كما ان الفكر اليهودي الإسرائيلي لا يرى في العرب اناسا ولا يعدهم بشرا بل مخلوفـات لنتنة) تلوت كل من يقترب منها، كدلك فعل عدد من الادباء اليهود الدين راحوا يمارسون الثتم والسباب العلني ضد العرب ويحاولون طس حضارتهم العربيه الإسلاميه الإنسانيه السمحه، وهكدا وعل الثاعراحاييم حيقر) في وصيدته (نظريتهم

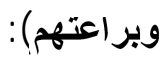

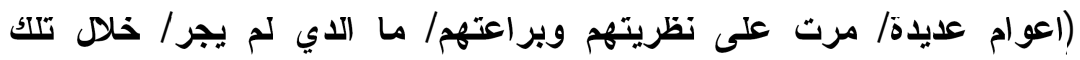

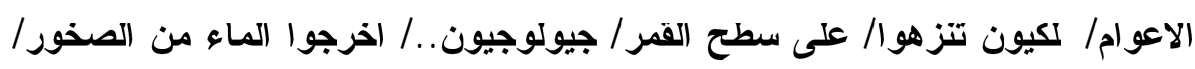
مختصون بامراض القلب/ مهندو وراته/ عقول حلت ملايين الخلايا/ وهناك.../ عنده صمت الموت/ صحر اء خلقيه/ ببساطه.... مستقع) (A - (1).. 
ويشبه الشاعر العبري (ايسرائيل هار) العرب بالعشب الضار الدي يجب ان يداس او يقطع هم، حسب رايه، يستهلكون حتى الهواء ويحرمون اليهود منه، ويقول وي وصـــيدته (وصيه): (يتقاخر عليك ويستعلي/ بلخان حار/ يعلو في الممرات ويهبط/ في مساء مدينه تعبه/ يدور.../ ولا هداة لي../ عشب ديس/ وصار الدرس وصيه/ (وتلعته مرة اخرى/ ورميته خلفي/ كتيرة ميزات النبات../ تستهلك الريح

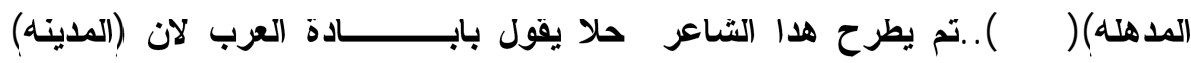
باتت ضيقه ولا مجال لتتسع للعرب واليهود معا، هالعرب، على حد زعمه، حبال وولاديه دائمه الجدل تحيط باعناق اليهود ويقول: (يتفاخر../ يقر ا../ يستعال../ والمدينه ضيقه/ ولا معين/ حبال فولاديه/ دائمه الجدل/ ولا هداة لي/ ها (تا دا..)( - 1 1 ).. ويعد الشاعر (ايلان بوسم) إلى وصف العرب بالغرباء وان الارض بوجودهم مجهوله والحياة تاوهه: (غرباء وي مدينتي/ بيوتات حديته البناء/ طرها شقت الان/ منظرا بلدل وجهه/ ارضا مجهوله/ حياة تاههه) (1 I )... (ما الشاعر (موشيه بن

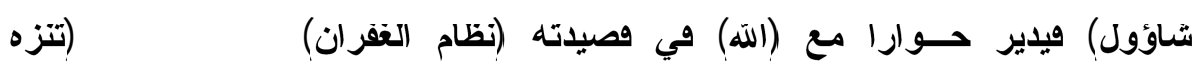
سبحله) لاته، حسب زعمه، تعمد اللامبالاة حيال الام اليهود التي تسبب بها العرب والاغيار عموما ولم يهب لتجدته، ويقول: (اغقر لنا وي عيد المظله.. اغقر لنا/ من اتت حتى تفقر لنا.../ حتى اغقر لك../ حملت روحي/ نقاط ضوء وي جبينك/ اغقر لنا في يوم الغــفران/ غقرت للك في الغقران) (I I ).. كما يقول له لنبحله تقال) بان اليهود ود غقروا كتيرا، ولكن الامر لم يعد يطاق قاتت تغفر (للكلاب) وتتركنا لوحشيتهم، قاما ان تقوم بعمل يتبت صهيونيتك ايها الإله و واما ان نكقر بك وعندئد ستخسر الكتير ..(IIr)

وتصور الثاعرة العبريه (أدوريت مارتون) في فصيدتها (لا اشجار) العرب

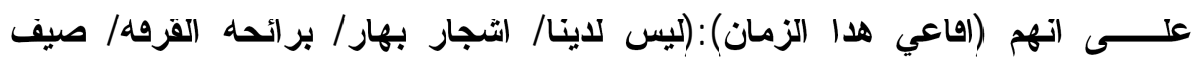

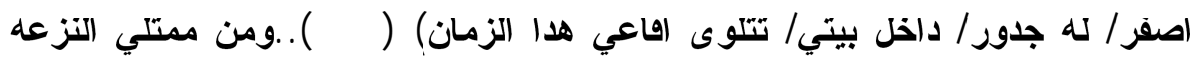
العنصريه في الشعر العبري المعاصر، الثاعرة (نعمي شيمر) التي كتبت فصيدة يغتيها

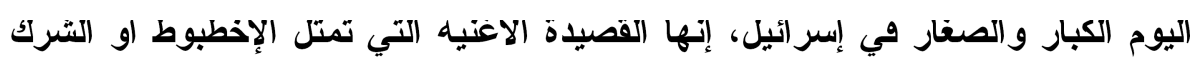


الاي تتصبه للعالم شاعرة كاتت ترى، وما تزال، في سحق العرب ووتلهم واجبا صهيونيا تمليه ولسفه العنف والحرب اليهوديه واصولها الدينيه والايديولوجيه: (ربما غدا سنبحر وي سفن/ من ساحل ايلات حتى ساحل العاج/ وعلى المدمرات القديمها

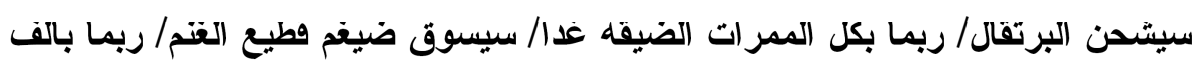

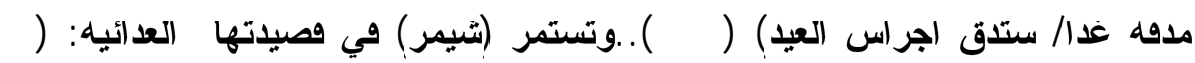

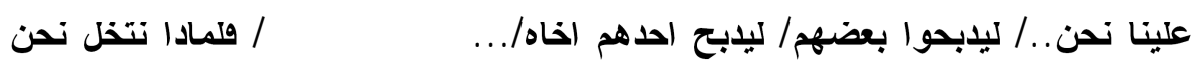

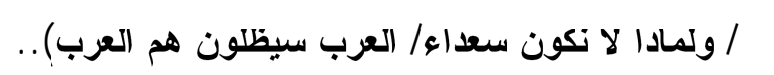

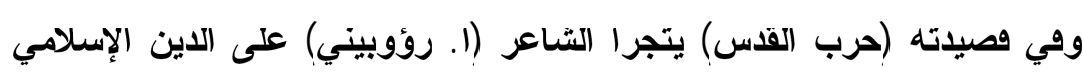
والاماكن الإسلاميه المقسه واصفا إياها (كناد للتامر) ويصور العرب وابلهيل المسلمين كوحوش بشريه، ويقول: (في مسجد عمر تجمع المحتشدون/ كان المسجد مغارة

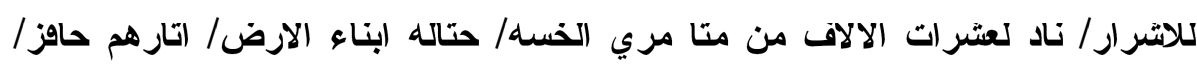

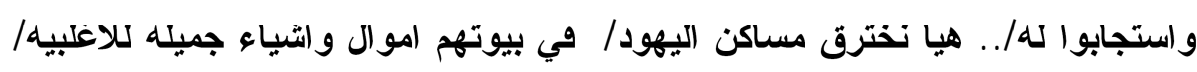

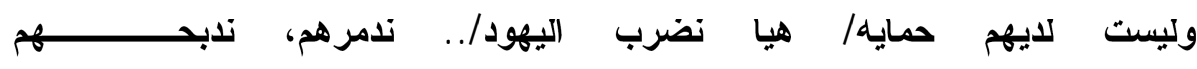
ونرتهم..(1)(

الخاتمها

لقد عمل هادة الفكر الإسرائيلي وفلاسفته على علم تفسير التاريخ اليهودي بمعزل عن الجواتب الاقتصاديه والقوميه والدينيه والجيوبوليتيكيه التي تهم اليهود هعدوا على تحويل العقيدة الدينيه إلى نظريه سياسيه تطالب بحق تاريخي مزعوم هي ولي وليه

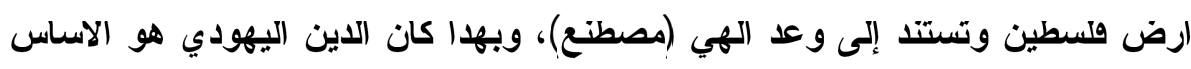

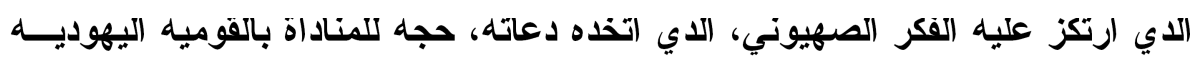

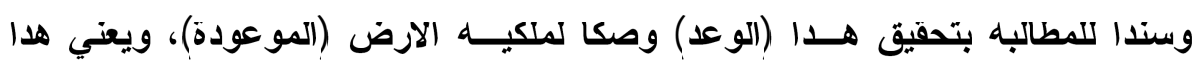
ان الفكر الإسرائيلي حدد ان الدين اليهودي هو الرابط بين ترات اليهود وماضيهم السحيق وبين تطلعاتهم الر اهنه واحلامهم المستقبليه.. واستتادا إلى هله المقاهيم بنت الحركه الصهيونيه ولسفتها وخطط وادتها مند

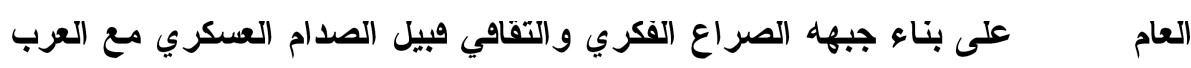


إدراكا منهم ان مجال المواجهه التقايهه هو الاخطر في مداه والاعمق في تاتيره ولالك اخدت هده الحركه على عاتقها رسم الاسلــوب وصياغه الوسيله لتحويل لإلحل) إلى (واقع) بلستبلحة ارض ولسطين، وما جاورها من اراض عربيه اخرى وتفريغها من سكانها العرب عن طريق الحرب والعنف والإرهاب واستخدام الادب العبري كإحدى الوسائل الفاعله لتحقيق هده الإستر اتيجيه...

لهها السبب لعب الادب العبري دورا مهما في خدمه الحركه الصهيونيه والترويج لاوكارها واهداوها وتبنى ولسقتها التي توخت إتارة الغزائز العدواتيه لاى اليهود من جهه والتقليل من تاتير القدرات الإنسانيه والترات الإنساتي من جهه تاتيه، وبللك شكلت العدواتيه سمات خطيرة في الشخصيه اليهوديه. كما تبنى الادب العبري، بسلوكيته المطروحه وغايته المنشودة الفلسفه الميكاهيليه بكل ابعادها وتخلى عن واجبات الابب الضروريه كالحق والخير والجمال، وتشبع ايضا بالمقولات الصهيونيه الزائفه واعتمادها على الاساطير الاينيه المبطنه مند البلايه وراح يصطنع مختلف الاساليب للتعبيز عنها، وظهر ادب لالروايه التاريخيـه) و ادب (الترات) وظهر ما سمي بادب (النكبه) وادب (الارتبـاط بالارض) وظهر ادب (الحرب)، إلى غير دلك من اساليب التعبيز الادبي المحكومه هي اتبتاهها من الدعاوى الصهيونيه داتها، عليه يمكن القول ان الادب العبري يقوم بضبط خطواته على جميع الجبهات متسلحا بكل الاسلحه الادبيه والفنيه، بما في دلك المبالغه وطمسس الحقائق والحرب التفسيه والاستخدام الاتتهازي لاحدات الماضي في تبريز احدات جديدة ووفائع مفتعله لخدمه اهداف المشروع الإسرائيلي الاستر اتيجي الاي وضع فبل ما يزيد عن صرن من الزمن والمتمتل بتاسيس (لدوله إسرائيل) كمرحله اولى واستمرار هده الدوله وتقويتها وتعزيز وجودها كي تكون قاعدة لإهامه (دوله إسرائيل الكبرى) كمرحله تانيه ومن تم تتفيد المرحله التالته وهي إفامه (ارض إسرائيل العظمى) حسب اساطير توراتيه مزعومه..

وللوفوف على هده الاتجاهات الصهيونيه وفلسـفتها من مصادرها الاصليه (العبريه) تم اختيار نمادج شعريه عبريه وترجمتها إلى العربيه وتحليلها كي تساعد 
في إلقاء الضوء على حقيقه الدور الإسرائيلي للادب العبري رغم ما ظهر مؤخرا من اوكار واتجاهات الدبيه عبريه تحاول تلميع صورة هلا الادب من مسائل مهمه كالسلام

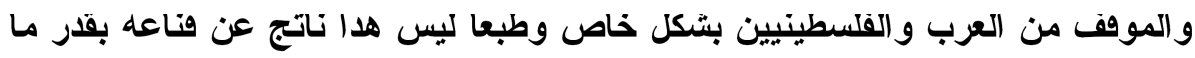
هو اضطرار فرضته الاحداث والتطورات والحروب التي شهاها الصراع العربي الإسر ائيلي ومداخلاته العربيه والإقليميه والدوليه خلال عقود من الزمن بالإضافه إلى عمليات المقاومه الفلسطينيه وتضحيات ابناء شعبنا القلسطيني وصمود ه الرائع الدي اربك اليهود وتسبب لهم في الام وخسائر لم يكونوا معتادين عليها، هده الحاله احتت انقساما داخل المؤسسه الإسرائيليه الحاكمه وبين اوساط المتقفين والادباء اليهود حول طريقه التعامل معها او التعبير عنها، لكن هلا الانقسام لا يصل إلى درجه التناصض التصن الجوهري او المبئي تجاه القضايا الاساسيه للمستوطنين اليهود، وصد عبر عن هده الصورة اكتر من اديب وشاعر خلاصتها ما ورد على لسان الاديبه إحافه بنــــاس

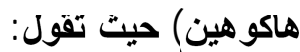

(إن الصعوبه يمكن ان تكون احيانا اللحظه الاوضل للاهر اد والثعوب، لان

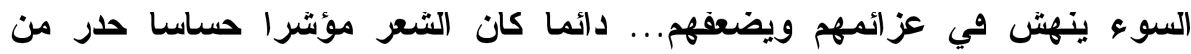
الهزات الارضيه فبل حدوتها. والان، وبينما تتهار البيوت على رؤوس ساكنيها وينتشر الموت في كل مكان يتوفف مؤشر الهزات في مكانه.. هله ايام صعبه على السياسيين

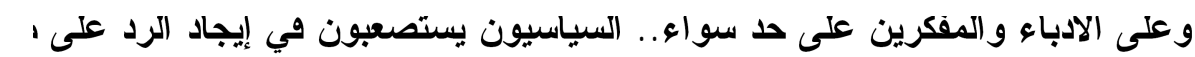

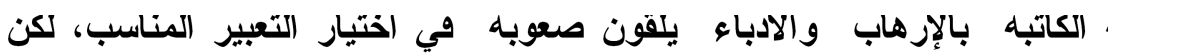
خلاها للعاملين على ارض الواقع من الداين عليهم ان يسعون لإيجاد الحل المناسب لإباء و القيام بشيء ما، تبدو اجندة الادب العبري مختلفه، وض يكون رده المتاخر هاسيا وهويا

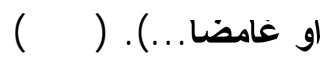




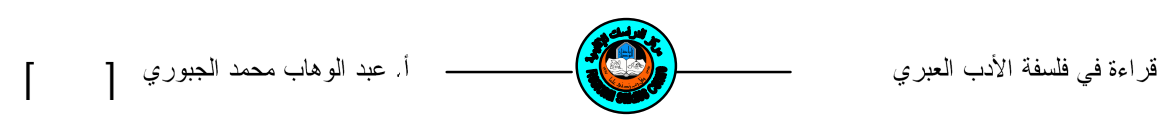

\title{
Israeli Literature Trends And Its Philosophy
}

\begin{abstract}
Abdul-Wahab Mohammed AL- juburi
Abstract

Jewish literature since its beginning has filled up with opinions of Zionist movement. Jewish men of letters have a doped these opinions and that movement stood aside in order not to induce the Jews and to attract them towards Palestine educating the children and the young to be the land of the whole Israel. The paper is an attempt to study the Jewish literature and its philosophy and its relation with the Zionist movement. It also presents models of Zionist dimensions insisting that the Jewish religion is the basic tie between their legacy and their past from one side and the current prospects and the future dreams from another.
\end{abstract}




\section{الهو امش و المصادر}

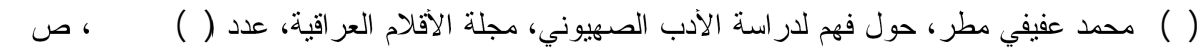

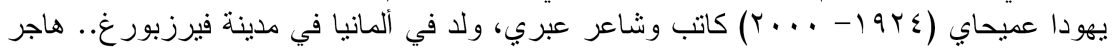

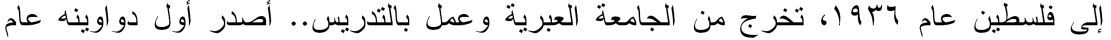

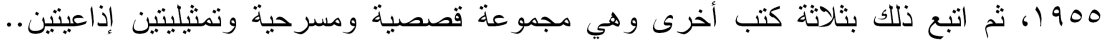

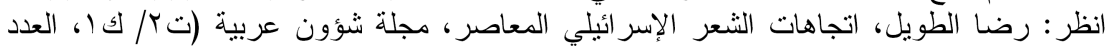

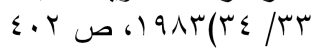

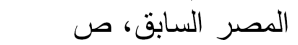
د. عبدالو هاب محمد المسيري، اليهو دية و الصهيونية و إسر ائيل، المؤسسة العربية للار اسات و النشر ،

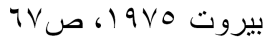

فائزة عبدالامبر نايف الهايب، الاتجاهات الصهيونية في الادب العبري الحديث، رسالة ماجستبر

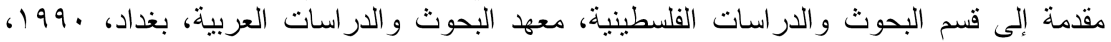
ص م

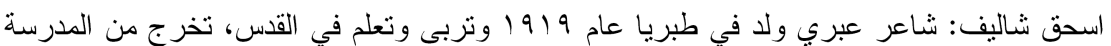

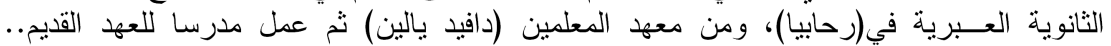

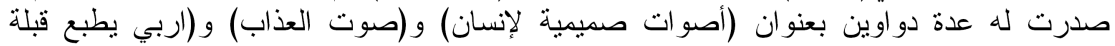

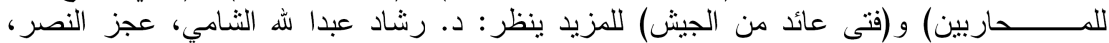

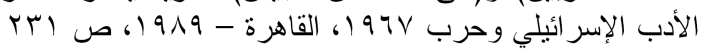

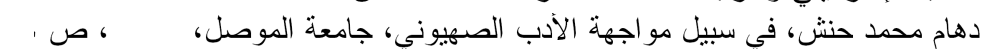

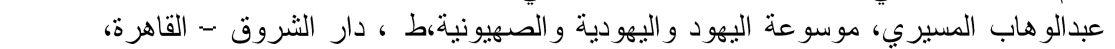
حسن حمبد، الأدب العبري/ المرجعيات - المصطلحات - الرؤى(در اسة) دار السوسن للار اسات

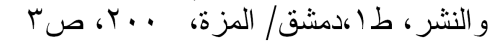

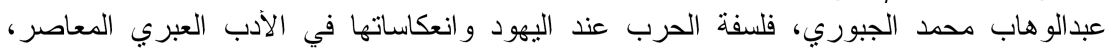

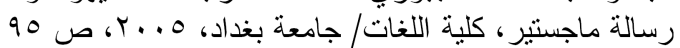

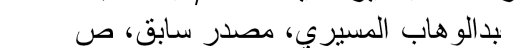

$$
\begin{aligned}
& \text { ( } \\
& \text { المصدر نفسه، ص صن } 10
\end{aligned}
$$

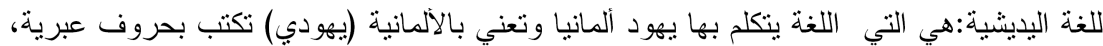

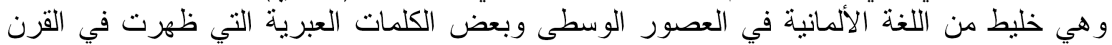

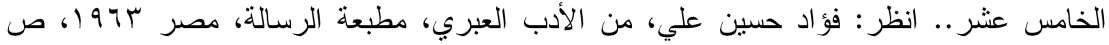
rIV

د. عبدالو هاب المسيري، موسو عة اليهود و اليهودية و الصهيونبة، مصدر سابق، ص بrس

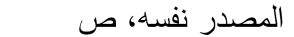

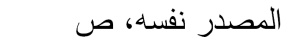

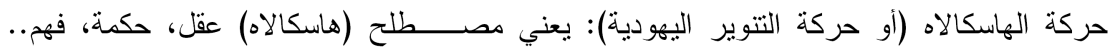
(r.)

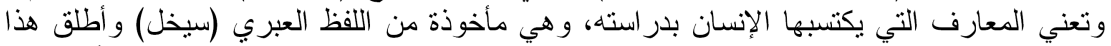

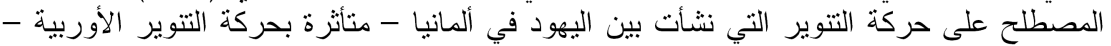

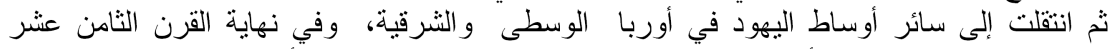

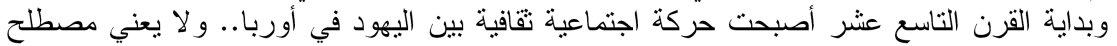

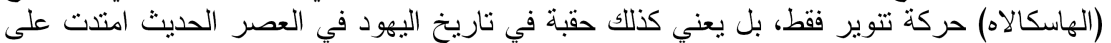




\section{「Iv9]}

أ. تعبد الوهاب محمد الجبوري

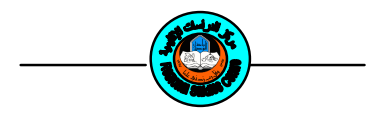

قر اءة في فلسفة الأدب العبري

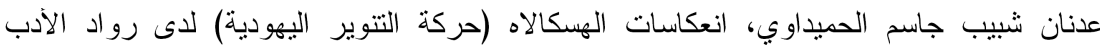

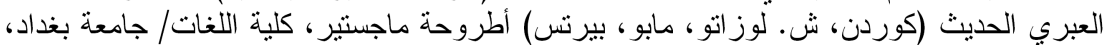
999

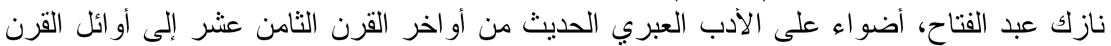

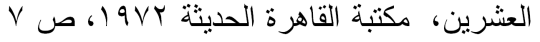
رشاد الثنامي، لمحات من الأدب العبري الحديث مع نماذج مترجمة، مكتبة مكتبة سعيد رأفت، القاهرة،

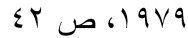

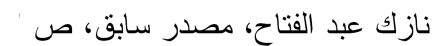

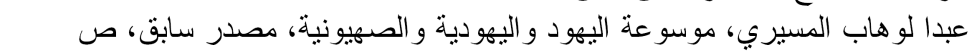

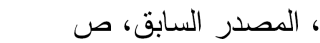

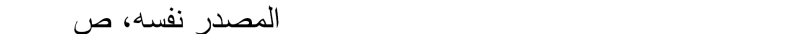
حامد عبدا لله ربيع، الدعاية الصهيونية، المنظمة العربية للتزبية و الثقافة و العلوم، الجيزة، 19V9 ، ص صامد

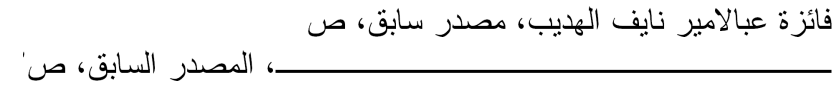

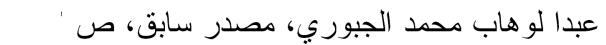

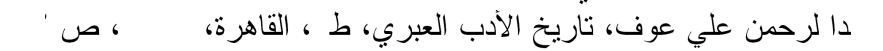

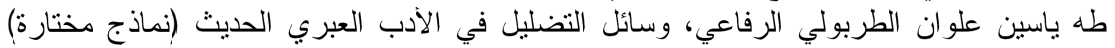

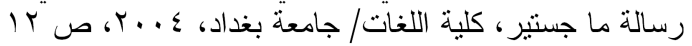

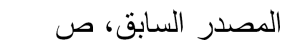

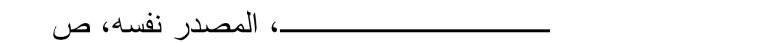

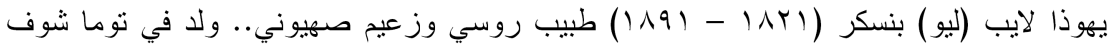

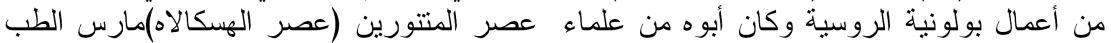

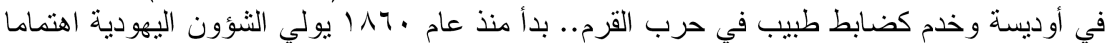

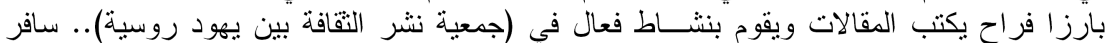

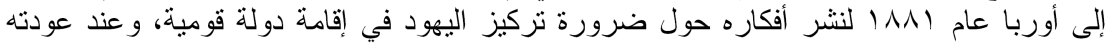

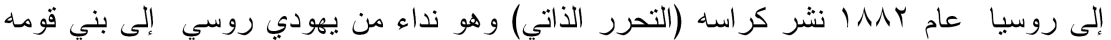

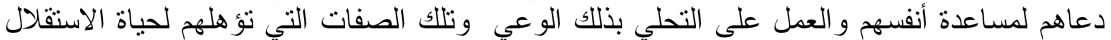

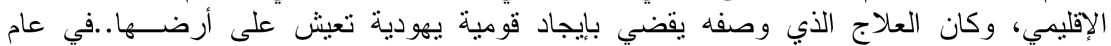

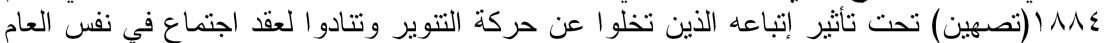

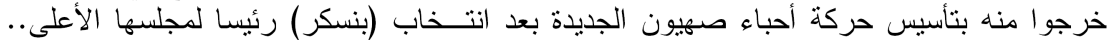

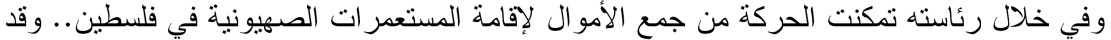

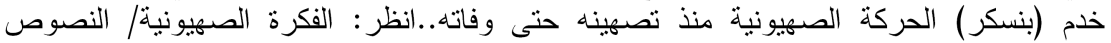

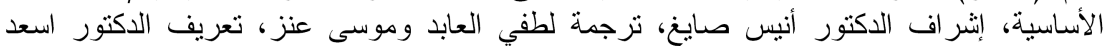

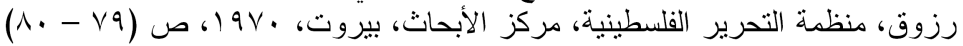

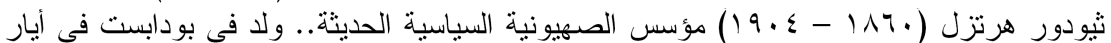

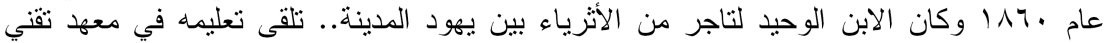

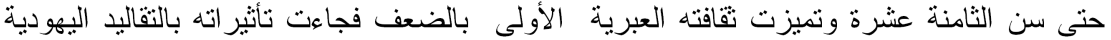

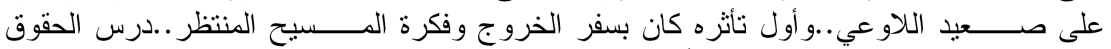

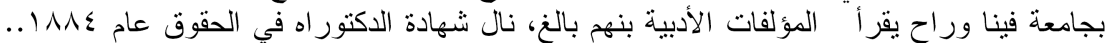

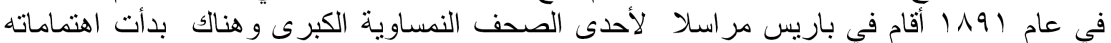

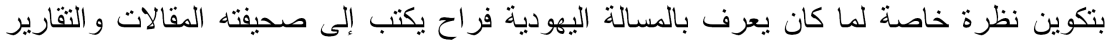


حول الثنؤون اليهودية، وكان برى في عداء العالم لليهود نو عا من التربية القاسبة لهمه.. في أواخر

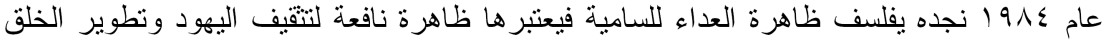

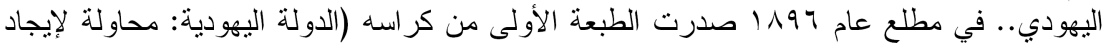

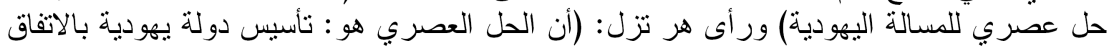

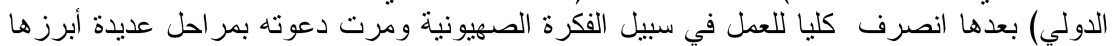

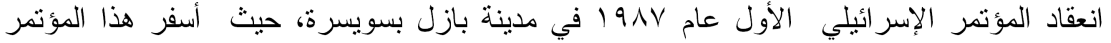

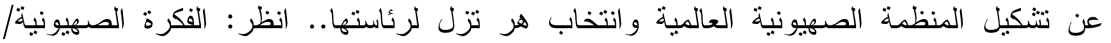

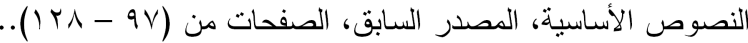

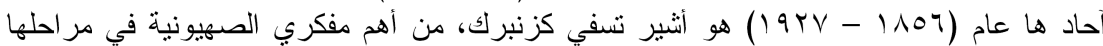

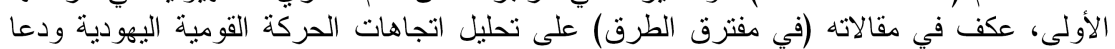

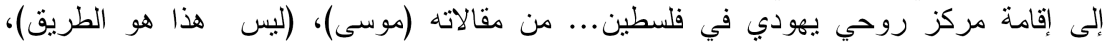

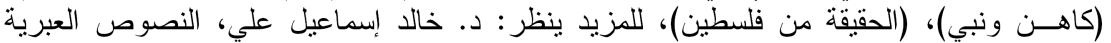

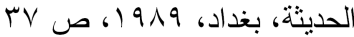

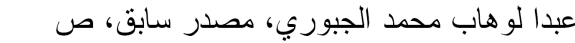

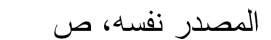

علي عبدا لرحمن، القصة العبرية المعاصرة بين الحلم الإسرائيلي و والكابوس الصليبي، عبر الفير الانترنيت،

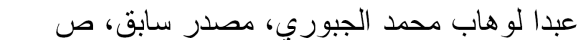

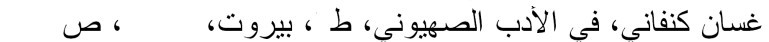

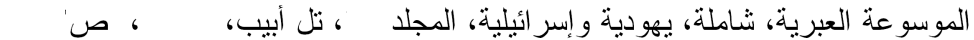

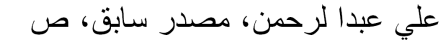

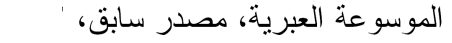

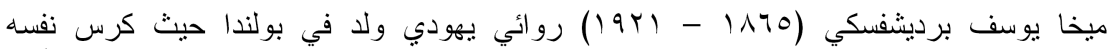

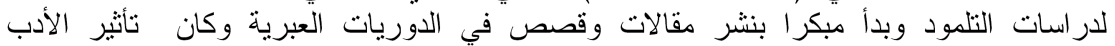

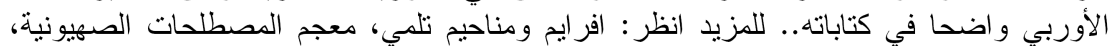

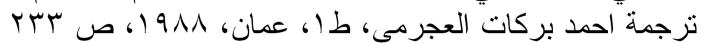

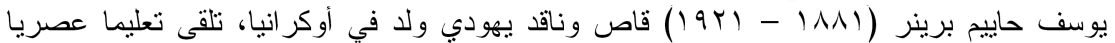

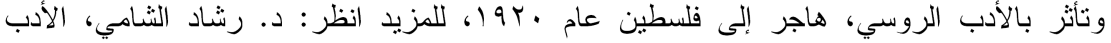

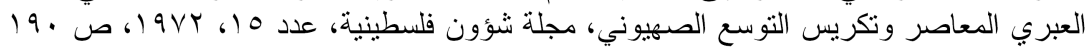

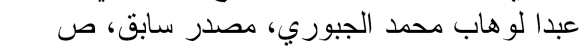

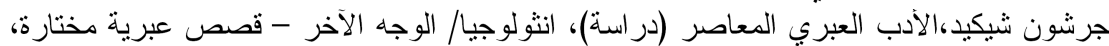

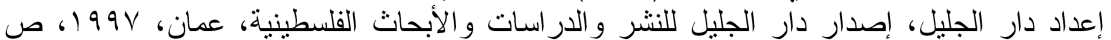

$\left(r^{\mu}-9\right)$

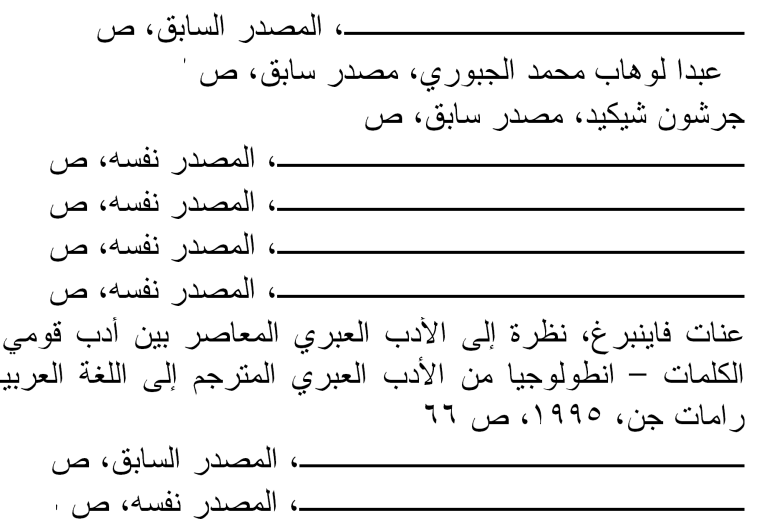

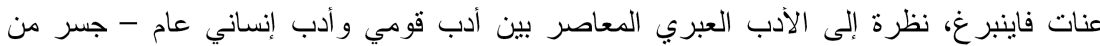

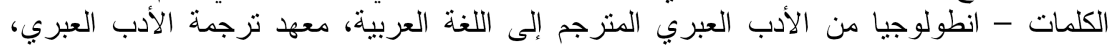




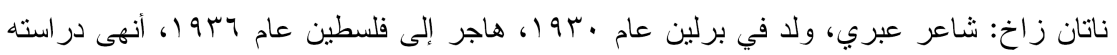

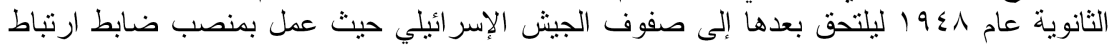

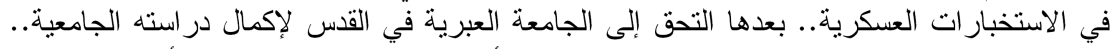

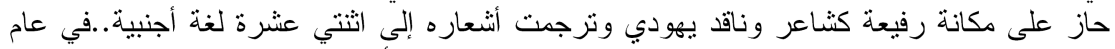

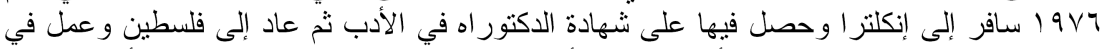

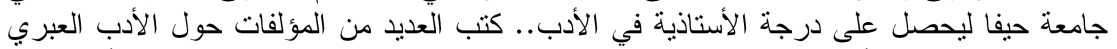

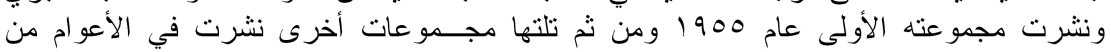
(19^ع - 197.)

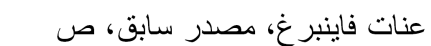

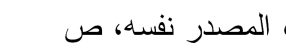

خبري منصور، الرؤية العربية للادب الصهيوني، مجلة الآقلام العر اقية، عدد خاص الفه في الأدب

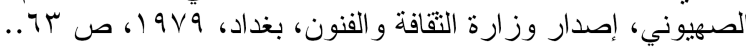

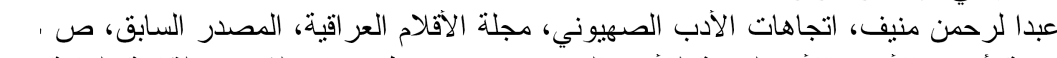

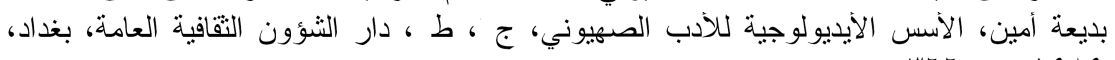

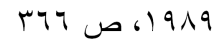

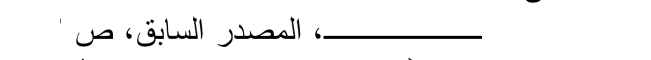

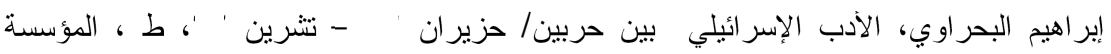

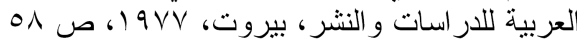

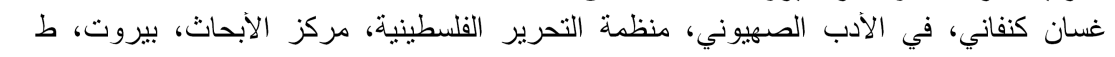
19v1 صالح ألعباري، في الثعر العبري و الإسرائبلي المعاصر، طا، دمثق، دار طلاس، 9^Vا، ص (1) - 10)

مختار ات من الثتعر العبربي المعاصر ، نزجمة البروفيسسور (رؤوبين سنبر)، عبر الانترنيت (VI)

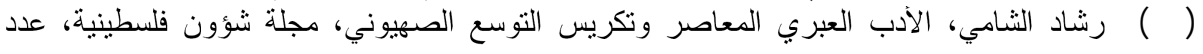

190 ،

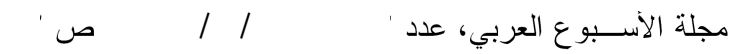

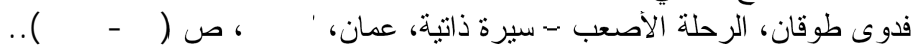

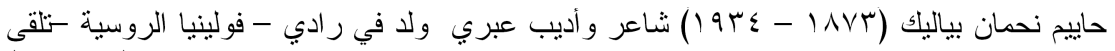

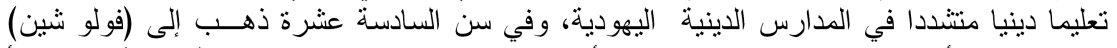

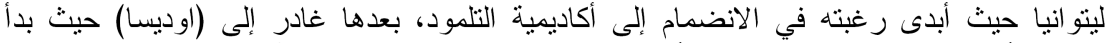

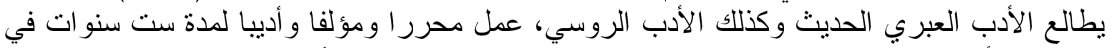

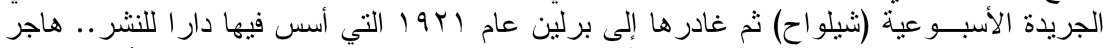

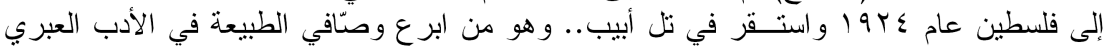

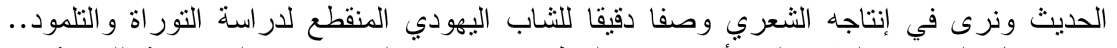

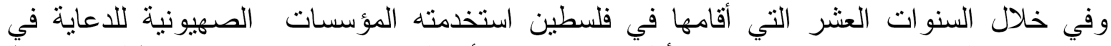

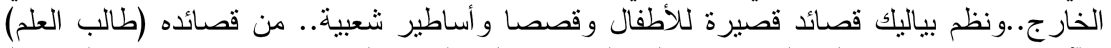

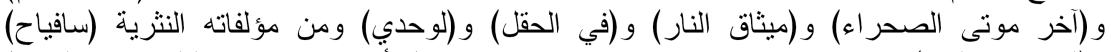

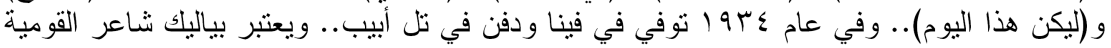

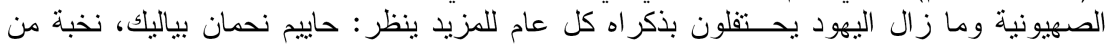

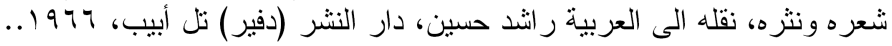

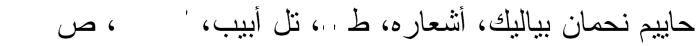
أهرون رؤوبيني، أنتعاره، القدس، 


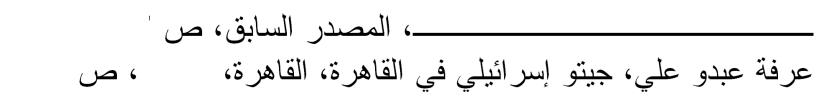

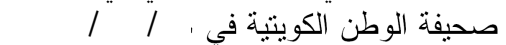

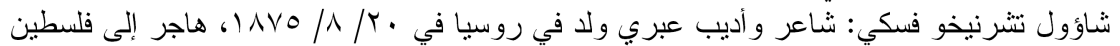

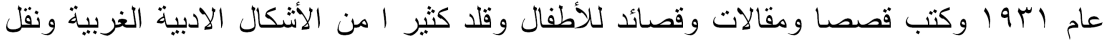

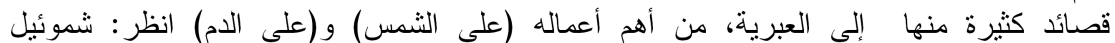

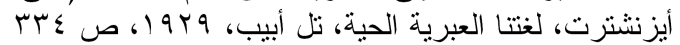

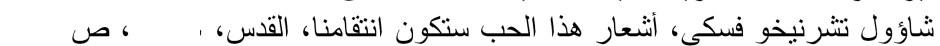

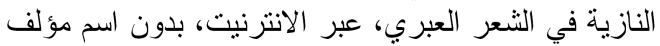

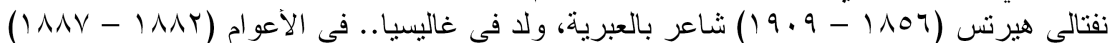
$(\Lambda r)$

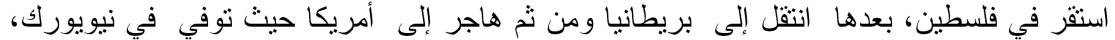

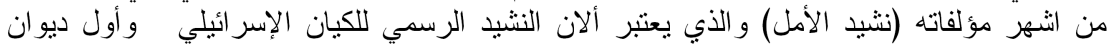

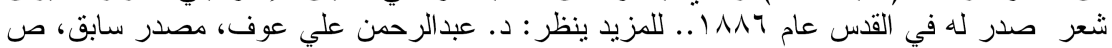
Iย१

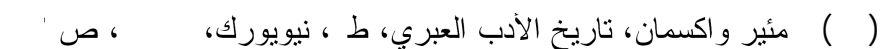
(17)

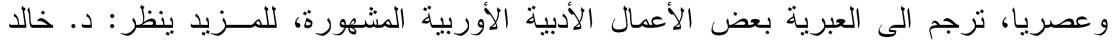

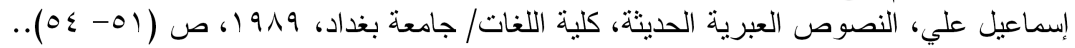

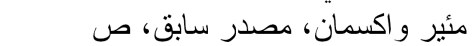

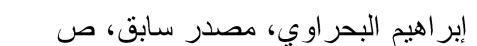

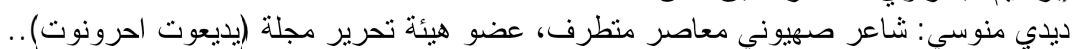

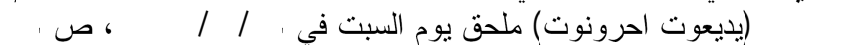

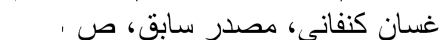

الزوهر : كلمة عبرية تعني (الضياء) وكتاب الزوانية هر هو أهم كتب التزراث اليهودي الصوفي (القبالي) (१)

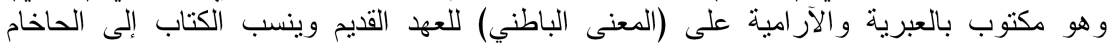

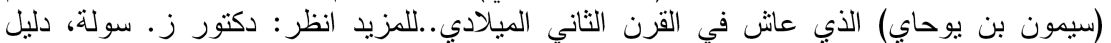

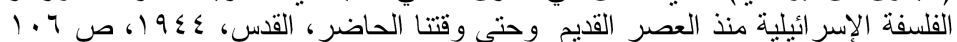

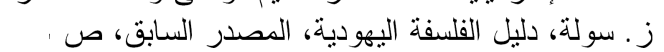

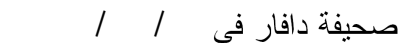

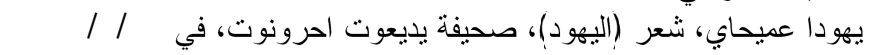

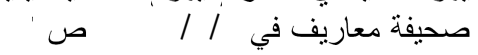

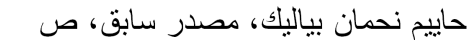

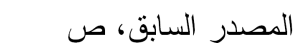

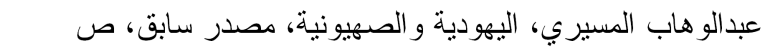

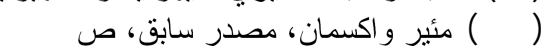

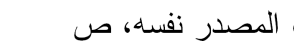

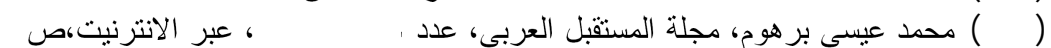

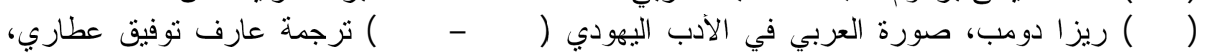

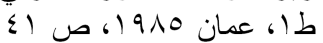

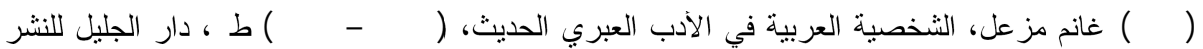

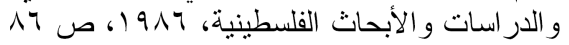

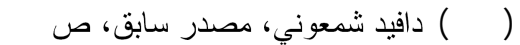

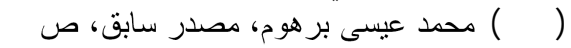

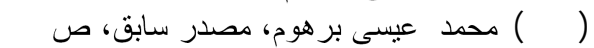

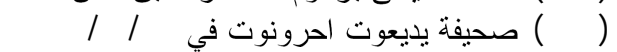




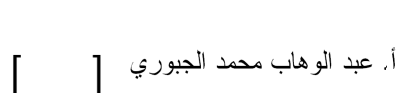

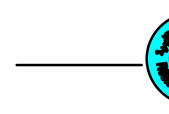

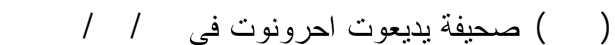

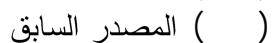

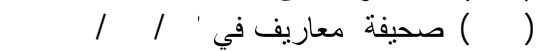

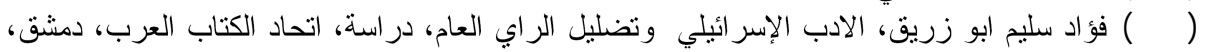

117...

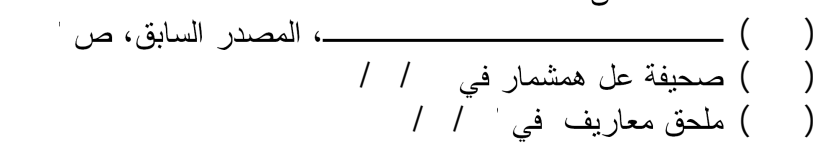

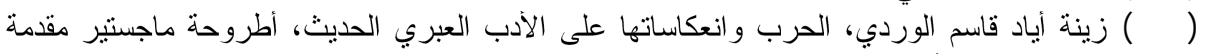

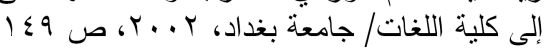

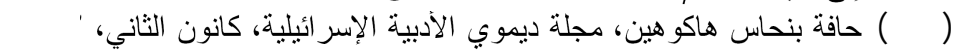

